\title{
Small in Size, but Large in Action: microRNAs as Potential Modulators of PTEN in Breast and Lung Cancers
}

\author{
Asal Jalal Abadi ${ }^{1}$, Ali Zarrabi ${ }^{2}{ }^{\mathbb{D}}$, Mohammad Hossein Gholami ${ }^{3}$, Sepideh Mirzaei ${ }^{4}$, Farid Hashemi ${ }^{5}$, \\ Amirhossein Zabolian ${ }^{6}$, Maliheh Entezari ${ }^{1}$, Kiavash Hushmandi ${ }^{7}$, Milad Ashrafizadeh $2,8, * \mathbb{D}$, Haroon Khan ${ }^{9, *}$ \\ and Alan Prem Kumar 10,11,*1D
}

check for updates

Citation: Abadi, A.J.; Zarrabi, A.; Gholami, M.H.; Mirzaei, S.; Hashemi,

F.; Zabolian, A.; Entezari, M.;

Hushmandi, K.; Ashrafizadeh, M.; Khan, H.; et al. Small in Size, but Large in Action: microRNAs as Potential Modulators of PTEN in Breast and Lung Cancers. Biomolecules 2021, 11, 304. https:// doi.org/10.3390/biom11020304

Academic Editor: Rami I. Aqeilan Received: 24 January 2021

Accepted: 15 February 2021

Published: 18 February 2021

Publisher's Note: MDPI stays neutral with regard to jurisdictional claims in published maps and institutional affiliations.

Copyright: (c) 2021 by the authors. Licensee MDPI, Basel, Switzerland. This article is an open access article distributed under the terms and conditions of the Creative Commons Attribution (CC BY) license (https:/ / creativecommons.org/licenses/by/ $4.0 /)$.
1 Department of Genetics, Faculty of Advanced Science and Technology, Tehran Medical Sciences, Islamic Azad University, Tehran 193951495, Iran; Asal_jalali@yahoo.com (A.J.A.); entezarimali@yahoo.com (M.E.)

2 Sabanci University Nanotechnology Research and Application Center (SUNUM), Tuzla 34956, Istanbul, Turkey; alizarrabi@sabanciuniv.edu

3 Faculty of Veterinary Medicine, Kazerun Branch, Islamic Azad University, Kazerun 7319866451, Iran; hoseingholami2020@yahoo.com

4 Department of Biology, Faculty of Science, Islamic Azad University, Science and Research Branch, Tehran 193951495, Iran; sepidehmirzaei.smv@gmail.com

5 Department of Comparative Biosciences, Faculty of Veterinary Medicine, University of Tehran, Tehran 1417466191, Iran; faridhashemi172@gmail.com

6 Young Researchers and Elite Club, Tehran Medical Sciences, Islamic Azad University, Tehran 193951495, Iran; ah_zabolian@student.iautmu.ac.ir

7 Department of Food Hygiene and Quality Control, Division of Epidemiology, Faculty of Veterinary Medicine, University of Tehran, Tehran 1417466191, Iran; houshmandi.kia7@ut.ac.ir

8 Faculty of Engineering and Natural Sciences, Sabanci University, Orta Mahalle, Üniversite Caddesi No. 27, Orhanl, Tuzla 34956, Istanbul, Turkey

9 Department of Pharmacy, Abdul Wali Khan University, Mardan 23200, Pakistan

10 NUS Centre for Cancer Research (N2CR), Yong Loo Lin School of Medicine, National University of Singapore, Singapore 119228, Singapore

11 Cancer Science Institute of Singapore and Department of Pharmacology, Yong Loo Lin School of Medicine, National University of Singapore, Singapore 117599, Singapore

* Correspondence: milad.ashrafizadeh@sabanciuniv.edu (M.A.); haroonkhan@awkum.edu.pk (H.K.); apkumar@nus.edu.sg (A.P.K.)

Abstract: MicroRNAs (miRNAs) are well-known regulators of biological mechanisms with a small size of 19-24 nucleotides and a single-stranded structure. miRNA dysregulation occurs in cancer progression. miRNAs can function as tumor-suppressing or tumor-promoting factors in cancer via regulating molecular pathways. Breast and lung cancers are two malignant thoracic tumors in which the abnormal expression of miRNAs plays a significant role in their development. Phosphatase and tensin homolog (PTEN) is a tumor-suppressor factor that is capable of suppressing the growth, viability, and metastasis of cancer cells via downregulating phosphatidylinositol 3-kinase (PI3K)/protein kinase B (Akt) signaling. PTEN downregulation occurs in lung and breast cancers to promote $\mathrm{PI} 3 \mathrm{~K} /$ Akt expression, leading to uncontrolled proliferation, metastasis, and their resistance to chemotherapy and radiotherapy. miRNAs as upstream mediators of PTEN can dually induce/inhibit PTEN signaling in affecting the malignant behavior of lung and breast cancer cells. Furthermore, long non-coding RNAs and circular RNAs can regulate the miRNA/PTEN axis in lung and breast cancer cells. It seems that anti-tumor compounds such as baicalein, propofol, and curcumin can induce PTEN upregulation by affecting miRNAs in suppressing breast and lung cancer progression. These topics are discussed in the current review with a focus on molecular pathways.

Keywords: microRNA; cancer therapy; PTEN; lung cancer; breast cancer; long non-coding RNA; circular RNA 


\section{Introduction}

Lung and breast cancers are malignant thoracic tumors. Lung cancer is a leading cause of death worldwide that has a 5-year survival rate as low as $18 \%$ [1]. In most cases of lung cancer (up to $80 \%$ ), operation is not practical because of the delay in cancer diagnosis [2,3]. Consequently, a minor improvement has been achieved in survival rate. Annually, 220,000 patients with lung cancer are diagnosed in U.S.A where tobacco smoking is the major reason for its development [4-6]. Late diagnosis and metastasis into other vital organs of body such as the liver, bone, and nervous system are responsible for the poor prognosis of lung cancer patients [7-9]. Lung cancers are embedded to two major categories including small cell lung cancer (SCLC) and non-small cell lung cancer (NSCLC) in which NSCLC comprises most of lung cancer cases (up to 88\%) [10,11]. Each of them has its subcategories. For instance, lung adenocarcinoma, lung squamous cell carcinoma, and large cell carcinoma are subcategories of NSCLC [10]. The normal structure of lung includes bronchiole and thin-walled alveoli surrounded by blood vessels. When lung cancers are developed, this normal structure is impaired by the penetration of tumor cells and stroma, providing an inflammatory response [7].

Similar to lung cancer, breast cancer remains a leading cause of death with high morbidity and mortality. According to estimates, one in eight British women are diagnosed with breast cancer [12-14]. The 5-year survival rate of breast cancer patients is dependent on stage, so that breast cancer patients in stage 1 or 2 have good 5-year survival rates of as much as $80 \%$, but this number diminishes to $15 \%$ in stage $4[12,15,16]$. So, early diagnosis of breast cancer is of importance in its treatment and improving prognosis. Breast cancer is a heterogenous disease that can be divided into four categories based on the presence or absence of hormone receptors for estrogen, progesterone, and human epidermal growth factor receptor 2 (HER2) $[15,16]$. Lung and breast cancers are caused by multiple factors that have not been understood completely $[17,18]$. However, attempts have been conducted in improving knowledge toward genetic factors responsible for the development and progression of these thoracic cancers. MicroRNAs (miRNAs), as non-coding and short RNA molecules, are considered as potential diagnostic, therapeutic, and prognostic factors for breast and lung cancers $[19,20]$. There are two major types including tumor-suppressor and tumor-promoting miRNAs whose roles in the development of breast and lung cancers have been elucidated [21-24]. In the case of lung cancer, miRNAs have demonstrated capability to affect proliferation and metastasis. In this way, numerous factors are affected by miRNAs. For instance, miRNA-195 and miRNA-497 can disrupt lung cancer progression and colony formation via upregulating transforming growth factor-beta (TGF- $\beta$ ) [25]. There are also miRNAs that facilitate lung cancer malignancy. miRNA-143-3p stimulates N6methyladenosine in elevating the brain metastasis of lung cancer cells [26]. Bone metastasis of lung cancer cells can be inhibited by miRNA-192-5p via the negative regulation of TRIM44 [27]. When the growth and migration of lung cancer cells enhance, they can induce chemoresistance. miRNA-27b suppresses epithelial-to-mesenchymal transition (EMT) via Snail downregulation to reverse chemoresistance [28].

A similar story is observed in breast cancer cells. Both tumor-suppressor and tumorpromoting miRNAs have been recognized in breast cancer. Tumor-promoting ones such as miRNA-532-5p elevate breast cancer proliferation via ras-related and estrogen-regulated growth inhibitor (RERG) downregulation [29]. In contrast, tumor-suppressor miRNAs such as miRNA-539 prevent breast cancer proliferation via specificity protein 1 (SP1) inhibition [30]. It is noteworthy that miRNA-7 is capable of suppressing the activity and expression of drug transporters including multidrug resistance protein 1 (MRP1) in inducing chemosensitivity [31]. Studies demonstrate that miRNAs are key players in breast cancer [32,33], and investigating their expression is of interest in providing therapeutics.

The role of miRNAs in breast and lung cancers is due to capability in regulating molecular pathways and cellular events. Dysregulation in miRNA expression is correlated with cancer development [34-36]. In the present review, our aim is to reveal the role of miRNAs in the progression/inhibition of lung and breast cancer cells, with a focus on their 
relationship with phosphatase and tensin homolog (PTEN). This review is based on newly recorded articles and providing a new insight toward signaling networks involved in lung and breast cancers in which miRNAs and PTEN are key players.

\section{MicroRNAs in Oncology}

The function of miRNAs in regulating gene expression is mediated by attachment to $3^{\prime}$-untranslated region (3'-UTR) of messenger RNA (mRNA) to inhibit gene expression [37-40]. The complexity of miRNA function is due to the capability of miRNAs to affect more than one mRNA and the presence of several miRNA binding sites at one $3^{\prime}$-UTR. Numerous miRNAs have been recognized to date with multiple functions [41]. The first discovery of miRNAs occurred in Caenorhabditis elegans, and significant research revealed conserved miRNAs in other species, including human with different actions [42]. In addition to development, miRNAs participate in the regulation of precise and accurate cellular events including apoptosis [43], autophagy [44], differentiation [45], migration [46], angiogenesis [47], and so on.

As an explosion has been observed in research about miRNAs, not it is obvious that miRNAs are therapeutic targets in cancer therapy. As normal and cellular events are regulated by miRNAs, and complicated signaling networks comprising upstream and down-stream mediators are involved, miRNA expression disturbance is correlated with cancer development [48-50]. Such pathways and roles have been examined in different cancers to shed some light on the relationship between miRNA expression and cancer emergence. It has been reported that one miRNA can affect the expression of another one. For instance, miRNA-145 enhances the expression of miRNA-133b via promoter methylation caused by c-Myc and DNMT3A [51]. Tumor-promoting miRNAs enhances cancer growth and provide ignorance of cancer cells toward apoptosis [52]. Serum levels of such miRNAs such as miRNA-1290 and miRNA-1246 can be considered as diagnostic factors [53]. In contrast, there are miRNAs with an inhibitory impact on cancer growth. miRNA-181a significantly increases cisplatin sensitivity in cervical cancer cells via apoptosis induction [54]. miRNA-200c enhances breast cancer sensitivity to trastuzumab via stemness inhibition [55]. It can be highlighted that the proliferation and metastasis of cancer cells are modulated by miRNAs [56,57]. Those miRNAs that promote cancer malignancy are involved in chemoresistance [58], while tumor-suppressor miRNAs induce chemosensitivity [59]. In fact, miRNAs regulate cellular events, and dysregulation in their expression leads to cancer emergence. In this way, all aspects of cancer cells such as growth, invasion, and their response to therapy are affected by miRNAs. Notably, molecular pathways such as nuclear factor erythroid 2-related factor 2 (Nrf2) [60], Wnt [61], Signal Transducer And Activator Of Transcription 3 (STAT3) [62], and Zinc Finger E-Box Binding Homeobox (ZEB) [63] are a few of the down-stream targets of miRNAs in cancer. Furthermore, there are molecular pathways that are capable of functioning as upstream mediators and regulating the expression of miRNAs such as circular RNAs (circRNAs) [64], and long non-coding RNAs (lncRNAs) [65]. Revealing such interactions can pave the road into effective cancer therapy that is the aim of this review article.

\section{PTEN in Oncology}

\subsection{Signaling}

PTEN is a tumor suppressor factor with nucleus and cytoplasmic localization with various expressions in healthy and cancerous cells $[66,67]$. In order to provide a better understanding of PTEN signaling, first, the phosphatidylinositol 3-kinase (PI3K)/protein kinase B (Akt)/mammalian target of rapamycin (mTOR) axis should be described. At the first step of this axis, p110 induces the conversion of phosphatidylinositol-4,5-bisphosphate (PIP2) into phosphatidylinositol3,4,5-triphosphate (PIP3) through phosphorylation of the $3^{\prime}$-hydroxyl group [68-70]. PIP3 is an inducer of PI3K and leads to the recruitment of Akt to membrane via binding their pleckstrin homology $(\mathrm{PH})$ domains to PIP3 [71,72]. This interaction with PIP3 prevents the autoinhibition of Akt via phosphorylation at T308 by PDK1 and phosphorylation at S473 via mTOR [73-75]. This axis is further involved 
in promoting cancer cell proliferation, metastasis, and chemoresistance [9,76-81]. The cytoplasmic function of PTEN comprises of preventing PIP3 generation and inhibiting phosphorylation [82]. This action of PTEN suppresses the phosphorylation of p53 and activation of p21, resulting in preventing cell senescence. In addition to cytoplasmic functions, PTEN possesses nuclear functions including regulating genome stability and DNA repair (Figure 1) [83]. PTEN mutation in mice leads to genomic and chromosomal instability, revealing the nuclear function of this tumor suppressor factor that is independent of the $\mathrm{PI} 3 \mathrm{~K} / \mathrm{Akt} / \mathrm{mTOR}$ axis [84].

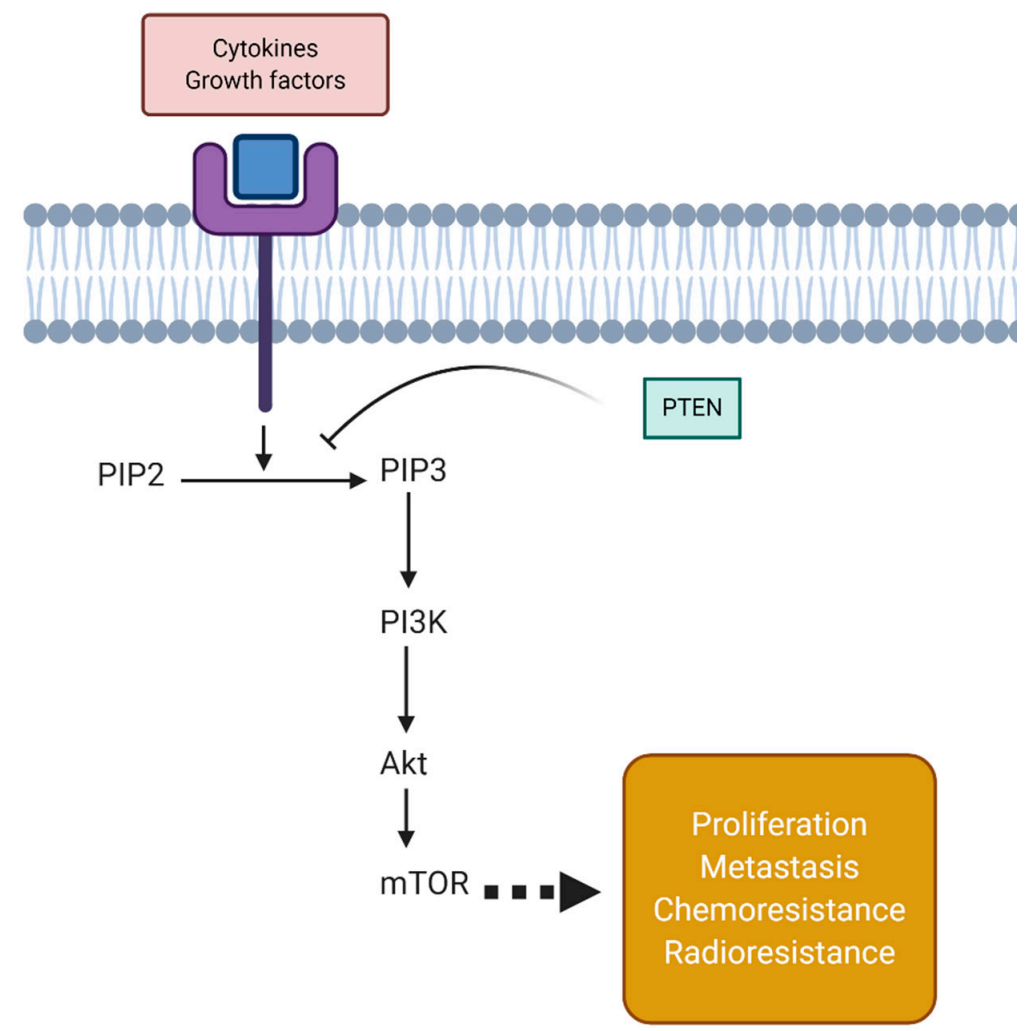

Figure 1. An overview of phosphatase and tensin homolog (PTEN) signaling. The cytokines and growth factors can induce the transformation of phosphatidylinositol-4,5-bisphosphate (PIP2) to phosphatidylinositol3,4,5-triphosphate (PIP3) by binding to a related receptor. Then, PI3K stimulates protein kinase B (Akt)/mammalian target of rapamycin (mTOR) signaling to induce the expression of genes involved in cancer progression, chemoresistance, and radioresistance. PTEN as a tumorsuppressing factor prevents PIP2 transformation to PIP3, restricting cancer malignancy.

\subsection{Role in Cancer}

As a negative regulator of PI3K/Akt/mTOR signaling, and having a tumor-suppressor role, the downregulation of PTEN expression can induce the malignant behavior of cancer cells [85]. A newly published experiment has shown that PTEN loss is correlated with resistance to CDK4/6 inhibitors via Akt stimulation [86]. It appears that PTEN loss in hair follicle stem cells leads to the development of squamous cell carcinoma, showing the tumor-suppressor role of PTEN [87]. When a decrease occurs in PTEN expression, the proliferation and viability of cancer cells undergoes an increase. This is due to the inhibition of glycolysis by PTEN as a factor involved in the promoted growth of cancer cells [88]. The interesting point is that anti-tumor compounds including cryptotanshinone suppress cancer proliferation and induce apoptosis via PTEN upregulation and the subsequent inhibition of PI3K/Akt/mTOR and nuclear factor-kappaB (NF-kB) pathways [89]. Dichloroacetate can suppress chemoresistance in cancer cells via the downregulation of miRNA-543, upregulation of PTEN, and inhibition of the PI3K/Akt axis [90]. EMT is associated with the metastasis of cancer cells [81,91]. PTEN inhibits EMT via Abi downregulation, 
which is of importance in disrupting breast cancer progression [92]. Studies are in line with the fact that both the proliferation and migration of cancer cells are negatively affected by PTEN $[93,94]$. As PTEN possesses anti-tumor activity, its downregulation is associated with undesirable prognosis [95]. In breast cancer, PTEN hypermethylation is associated with the risk of breast cancer development and can be used as a reliable biomarker in this case [96]. One clinical study demonstrates an enhanced incidence of PTEN hypermethylation in breast cancer patients [97]. The same phenomenon occurs for lung cancer, and PTEN hypermethylation is observed upon the progression and chemoresistance development of lung cancer cells [98].

Importantly, non-coding RNAs are potential upstream mediators of PTEN in different cancers. For instance, IncRNA Linc00702 inhibits cancer progression via enhancing PTEN expression and suppressing the PI3K/Akt axis [99]. In turn, IncRNA LINC00470 accelerates cancer proliferation through providing PTEN degradation [100]. Similar to lncRNAs, circular RNAs (circRNAs) are able to regulate PTEN expression in affecting cancer progression [101]. Notably, numerous studies have shed light on the relationship between miRNAs and PTEN. Apoptosis, autophagy, and proliferation of cancer cells are affected by miRNAs in different cancers $[102,103]$. As miRNAs are well-known regulators in cancer cells, understanding their impact on PTEN expression can be beneficial in providing novel therapeutics. In the next sections, a mechanistic discussion of PTEN regulation by miRNAs in breast and lung cancers is provided.

\section{MicroRNA and PTEN Relationship}

\subsection{MicroRNAs and PTEN Inhibition}

\subsubsection{Breast Cancer}

As PTEN has an inhibitory impact on the progression of breast cancer cells, its downregulation can occur by tumor-promoting miRNAs. miRNA-106b and miRNA-93 are potential factors in enhancing cancer growth and invasion via PTEN downregulation. This axis leads to activation of the PI3K/Akt pathway, which promotes cancer malignancy [104]. As PI3K/Akt participates in enhancing cancer growth, the way is paved to inducing chemoresistance. This statement can be confirmed by the effect of miRNA-2020-5p on PTEN expression in breast cancer cells. The miRNA-202 family has a dual role in cancer, exerting both tumor-promoting and tumor-suppressor roles [105]. As miRNA-202 demonstrates upregulation in human endometrium and adipose tissue-derived stem cells, it can be concluded that this miRNA family is involved in cell cycle regulation [106]. miRNA202-5p undergoes upregulation in drug-resistant breast cancer cells, while PTEN shows a decrease in expression. By an increase in miRNA-202-5p, the proliferation and drug resistance of breast cancer cells enhance, while apoptosis is inhibited. These malignant behaviors are mediated by PTEN downregulation via miRNA-202-5p and the subsequent induction of PI3K/Akt signaling [107]. Notably, clinical studies have also confirmed a relationship between miRNAs and PTEN. In this way, miRNA-144 has been shown to be upregulated in $22 \%$ of breast cancer cases, and PTEN has a low expression in $78 \%$ of cases. There is a negative relationship between PTEN and miRNA-144 in migratory breast cancer cells [108]. The downregulation of PTEN by microRNAs is mediated by binding to $3^{\prime}$-UTR. Introducing PTEN that lacks $3^{\prime}$-UTR for miRNA promotes its expression and suppresses breast cancer progression [109].

Exosomes are vesicle-shaped structures with a diameter of 50-150 nm that can transport miRNAs as cargo. Various exosomal miRNAs have been identified in breast cancer such as exosomal miRNA-455-5p, -1255a, and -148a that can be used as therapeutic and diagnostic factors $[110,111]$. Exosomal miRNAs are capable of regulating PTEN expression in ensuring breast cancer malignancy. It seems that exosomal miRNA-9 and miRNA-155 possess high expression in metastatic breast cancer cells. This increase in the aggressive behavior of breast cancer cells is mediated via downregulating PTEN [112]. It is worth mentioning that PTEN-regulating miRNAs can be considered as potential diagnostic factors in breast cancer. Serum levels of miRNA-214 as a regulator of PTEN can provide 
distinction between malignant and benign tumors, and healthy cells. Furthermore, the expression level of miRNA-214 undergoes downregulation after operation [113]. A same story occurs for miRNA-21, so that the expression of this miRNA is high in advanced stages and is associated with lymph node metastasis. Following miRNA-21 upregulation, the expression of PTEN demonstrates a decrease of as much as $80 \%$ [114]. The increased expression of miRNA-425-5p, as a negative regulator of PTEN, is observed in breast cancer that is associated with unfavorable prognosis [115].

Cancer stem cells (CSCs), also known as cancer-initiating cells (CICs), possess selfrenewal and multipotent differentiation potential that comprise a small proportion of tumor cells $[116,117]$. In breast cancer, $\mathrm{CD} 44^{+} / \mathrm{CD} 24^{-}$are considered as surface markers of breast cancer stem cells (BCSCs) $[118,119]$. Carcinogenesis, migration, and chemoresistance are mediated by BCSCs [120]. Previously, it was demonstrated that miRNA-222 and miRNA221 are negative regulators of PTEN in breast cancer progression. It appears that the aforementioned miRNAs possess regulatory impacts on BCSCs. By downregulating PTEN, miRNA-222 and miRNA-221 induce Akt phosphorylation to promote the growth and viability of breast cancer cells. miRNA-222 and miRNA-221 overexpression result in the enrichment of surface markers of CD44 ${ }^{+} / \mathrm{CD} 24^{-}$in BCSCs [121]. This study demonstrates that in addition to cancer cells [122], CSCs are also affected by miRNA and PTEN interaction. miRNA-10b functions as a double-edged sword in cancer. It exerts both tumor-promoting and tumor-suppressing roles in cancer [123-125]. In breast cancer, miRNA-10b possesses a tumor-promoting role by affecting CSCs. miRNA-10b maintains the self-renewal capacity of BCSCs by PTEN downregulation and paving the way for Akt activation. The prolonged activation of Akt leads to an increase in the self-renewal capacity and expression of cancer stem cell markers that are in favor of breast cancer malignancy [126].

The identification of miRNAs targeting PTEN is of interest in providing novel therapeutics. For instance, miRNA-182-5p diminishes PTEN expression in increasing breast cancer survival and invasion. Silencing miRNA-182-5p is correlated with an increase in PTEN expression and suppressing breast cancer malignancy [127]. The interesting point is that both the proliferation and metastasis of breast cancer cells are affected by the relationship between miRNA and PTEN. The overexpression of miRNA-29b results in apoptosis inhibition and cancer metastasis via PTEN downregulation [128]. It is noteworthy that miRNAs can diminish the impact of environmental factors in breast cancer development. Phthalates (PAEs) are endocrine-disrupting compounds, and their role in breast cancer progression and initiation has been confirmed $[129,130]$. Exposing breast cancer cells to butyl benzyl phthalate is correlated with an increase in proliferation, transition from the G1 to $S$ phase in the cell cycle, cyclin D1, the proliferation of cell nuclear antigen (PCNA), and a decrease in p21 expression. The investigation of molecular pathways demonstrates that butyl benzyl phthalate can bind to $3^{\prime}$-UTR of PTEN in reducing its expression, which is of importance for activating Akt and decreasing p21 expression [131]. These signaling networks provide breast cancer progression during exposure to environmental factors.

FOXO3a is an important member of the FOXO family with anti-tumor activity. In order to exert its inhibitory effect on cancer progression, FOXO3a should be stabilized in the nucleus. FOXO3a inhibition leads to breast cancer carcinogenesis [132]. FOXO3a overexpression is a desirable factor for prognosis, and its downregulation occurs in drug-resistant breast cancer cells [133]. Increasing evidence demonstrates that FOXO3a is a down-stream target of Akt [134-136]. As a tumor-promoting factor, miRNA-21 downregulates the expression of PTEN to induce Akt activation. Consequently, Akt stimulates the translocation of FOXO3a from the nucleus to the cytoplasm to prevent its anti-tumor action. Following FOXO3a downregulation, expressions of miRNA-34b and miRNA-34c undergo downregulation to increase CDK4 and CDK6 expression in favoring breast cancer progression [137]. Therefore, miRNAs are potential regulators of PTEN in breast cancer cells affecting proliferation, metastasis, and immune evasion [138]. These studies are in agreement with the fact that PTEN and its upstream and downstream mediators are in stringent surveillance of miRNAs affecting breast cancer progression and development (Table 1). 
Table 1. MicroRNAs (miRNAs) inhibiting PTEN in promoting breast cancer progression.

\begin{tabular}{|c|c|c|c|}
\hline miRNA & Signaling Network & Outcomes & Refs. \\
\hline $\begin{array}{l}\text { miRNA-106b } \\
\text { miRNA-93 }\end{array}$ & PTEN/PI3K/Akt & $\begin{array}{c}\text { Increasing cancer cell proliferation and metastasis } \\
\text { PTEN downregulation } \\
\text { Inducing PI3K/Akt signaling }\end{array}$ & [139] \\
\hline miRNA-182-5p & - & Silencing miRNA-182-5p impairs cancer malignancy via PTEN upregulation & [127] \\
\hline miRNA-221/222 & PTEN/Akt & $\begin{array}{l}\text { Promoting colony formation capacity } \\
\text { Inducing Akt signaling via PTEN inhibition }\end{array}$ & [121] \\
\hline $\operatorname{miRNA-19a/b}$ & PTEN/Akt/p21 & $\begin{array}{c}\text { Inhibiting cell cycle arrest at G1/S phase } \\
\text { Binding to 3'-UTR of PTEN in reducing its expression } \\
\text { P21 inhibition } \\
\text { Upregulating PCNA and cyclin D1 }\end{array}$ & [131] \\
\hline $\begin{array}{c}\text { miRNA-9 } \\
\text { miRNA-155 }\end{array}$ & - & $\begin{array}{l}\text { Involvement of these exosomal miRNAs in metastasis of breast cancer cells via } \\
\text { PTEN downregulation }\end{array}$ & [112] \\
\hline miRNA-10b & PTEN/Akt & $\begin{array}{l}\text { Maintaining self-renewal capacity of breast cancer cells } \\
\text { Akt hyperactivation via PTEN downregulation }\end{array}$ & [126] \\
\hline miRNA-221/222 & PTEN/Akt/NF-kB/COX-2 & $\begin{array}{c}\text { Enhancing stem cell-like features of breast cancer cells } \\
\text { Increasing colony formation capacity } \\
\text { Promoting stemness via ALDH1 upregulation } \\
\text { PTEN inhibition } \\
\text { Activating Akt/NF-kB/COX-2 axis }\end{array}$ & [140] \\
\hline miRNA-181c & - & Increasing cancer growth by binding to 3'-UTR of PTEN & [109] \\
\hline miRNA-425-5p & - & $\begin{array}{l}\text { Association with poor prognosis of breast cancer patients } \\
\text { Dually promoting cancer cell proliferation and metastasis } \\
\text { PTEN inhibition }\end{array}$ & [115] \\
\hline miRNA-30a & PTEN/Akt & $\begin{array}{l}\text { Downregulating PTEN expression } \\
\text { Providing condition for Akt phosphorylation } \\
\text { Promoting cancer cell survival and growth }\end{array}$ & [122] \\
\hline miRNA-21 & PTEN/Akt/ERK1/2 & $\begin{array}{c}\text { Silencing miRNA-21 disrupts cancer metastasis (EMT) via PTEN upregulation } \\
\text { and subsequent inhibition of Akt/ERK1/2 }\end{array}$ & [141] \\
\hline miRNA-19a-3p & - & $\begin{array}{l}\text { miRNA downregulation by cold atmospheric plasma leads to breast cancer } \\
\text { suppression via PTEN upregulation }\end{array}$ & [142] \\
\hline
\end{tabular}

\subsubsection{Lung Cancer}

Both miRNAs and PTEN can be considered as diagnostic and prognostic factors in lung cancer. For instance, miRNA-494 overexpression is associated with the poor prognosis, pathological tumor node metastasis (TNM), and lymph node metastasis of lung cancer cells. Furthermore, PTEN is associated with grade of differentiation [143]. Although this study has not evaluated miRNA and PTEN relationship in lung cancer, it shows that their expression is a determining factor for malignant behavior of lung cancer cells. Therefore, it is of significant importance to reveal miRNA and PTEN associations in lung cancer. The metastasis and growth of lung cancer cells mainly depend on the miRNA/PTEN axis. It has been reported that miRNA-106a binds to 3'-UTR of PTEN to reduce its expression, leading to lung cancer progression [144]. Decreasing the expression of such miRNAs causes the anti-apoptotic and pro-metastatic impacts to disappear by PTEN upregulation [145]. The aim of tumor-promoting miRNAs in PTEN inhibition is to activate PI3K/Akt signaling in increasing lung cancer progression [146]. Clinical studies have also confirmed miRNA and PTEN interaction in determining prognosis. It seems that miRNA93-5p upregulation is correlated with poor prognosis via PTEN downregulation [147]. It is noteworthy that miRNAs can synergistically regulate PTEN in lung cancer progression. miRNA-21 and miRNA-155 synergistically induce PTEN downregulation in enhancing lung cancer progression [148].

It was mentioned that miRNAs affect PTEN in triggering PI3K/Akt signaling. It appears that downstream targets of Akt play a significant role in lung cancer progression. S-phase kinase-associated protein 2 (Skp2) is a member of F-box family, and its overexpression in lung cancer cells mediates their resistance to cisplatin chemotherapy [149]. As a tumor-promoting factor, miRNA-1297 reduces PTEN expression to activate Akt signaling, leading to Skp2 expression and the malignant behavior of lung cancer cells [150]. It is worth mentioning that miRNAs can regulate the proliferation of cancer cells by targeting glycolysis. Hexokinase 2 (HK2) and pyruvate kinase isozyme M2 (PKM2) are two 
important enzymes in glycolysis. HK2 is involved in the first step of glycolysis and is a rate-limiting enzyme [151], while PKM2 participates in the last step of glycolysis [152]. By PTEN downregulation, miRNA-214 induces PI3K/Akt signaling, leading to HK2 and PKM2 upregulations, and paving the way for the progression of lung cancer cells [153]. Therefore, the growth, viability and invasion of lung cancer cells are mainly regulated by the miRNA/PTEN axis [154].

One of the interesting points is the relationship between PTEN and the immune system in cancer [155]. It has been reported that PTEN loss is associated with the activation of programmed death-ligand 1 (PD-L1), mediating the immune evasion of cancer cells [156]. miRNA-142-5p can reduce the cytotoxicity of CD4+ cells against lung cancer via PTEN inhibition. PI3K/Akt and PD-L1 activations occur following miNRA-142-5p upregulation in lung cancer [157]. Therefore, the miRNA/PTEN axis not only affects the proliferation and invasion of lung cancer but also regulates immune response. It is noteworthy that the response of lung cancer cells to radiotherapy can also be regulated by the miRNA/PTEN axis. In this way, miRNA-181a downregulates PTEN expression to promote the progression and malignancy of lung cancer cells, resulting in their resistance to radiotherapy [158]. Downregulating miRNA-21 and miRNA-95 expressions promote PTEN expression to suppress PI3K/Akt signaling, resulting in the radiosensitivity of lung cancer cells [159]. It has been reported that lung cancer cells can secrete extracellular vesicles for transferring miRNAs. The miRNA-23a transferring leads to PTEN downregulation in lung cancer cells exposed to radiation, leading to angiogenesis [160].

STAT3 and PTEN demonstrate interactions in cancer cells. IL-8 can reduce PTEN expression via phosphorylation to stimulate STAT3 signaling, resulting in enhanced cancer progression [161]. Furthermore, STAT3 can function as an upstream mediator of PTEN by activating lncRNA cancer susceptibility candidate 9 (CASC9) to diminish PTEN expression, resulting in bladder cancer progression [162]. On the other hand, miRNAs such as miRNA$551 \mathrm{~b}-3 \mathrm{p}$ can induce STAT3 signaling in enhancing the growth and metastasis of cancer cells [163]. Future studies can evaluate how miRNAs affect PTEN and STAT3 interaction in lung cancer. Taking everything into account, experiments demonstrate that miRNAs are versatile molecules in lung cancer by regulation PTEN signaling and affecting proliferation, invasion, and therapy response (Table 2) [164-170].

Table 2. miRNAs inhibiting PTEN expression in enhancing lung cancer progression.

\begin{tabular}{|c|c|c|c|}
\hline miRNA & Signaling Network & Outcomes & Refs \\
\hline miRNA-93 & LKB1/PTEN/CDKN1A/PI3K/Akt & $\begin{array}{c}\text { Upregulation of miRNA-93 in lung cancer cells } \\
\text { Association with proliferation and metastasis of cancer cells } \\
\text { Inhibiting LKB1/PTEN/p21 axis } \\
\text { Inducing PI3K/Akt }\end{array}$ & [171] \\
\hline miRNA-21 & PTEN/EMT & $\begin{array}{c}\text { Reverse relationship with PTEN } \\
\text { Promoting metastasis via EMT induction }\end{array}$ & [172] \\
\hline miRNA-21 & PTEN/Akt/GSK-3b & $\begin{array}{c}\text { Increasing cyclin D1 and cyclin E1 expressions } \\
\text { Enhancing cancer cell proliferation } \\
\text { Promoting metastasis via EMT induction } \\
\text { Activating Akt/GSK-3b signaling via PTEN downregulation }\end{array}$ & [173] \\
\hline miRNA-21 & - & $\begin{array}{l}\text { Enhancing cell proliferation and invasion } \\
\text { Apoptosis inhibition } \\
\text { PTEN inhibition }\end{array}$ & [174] \\
\hline miRNA-26a & PTEN/Akt & $\begin{array}{l}\text { Enhancing metastasis via PTEN downregulation and the subsequent } \\
\text { induction of Akt signaling }\end{array}$ & [175] \\
\hline miRNA-21 & - & $\begin{array}{c}\text { Binding to } 3^{\prime} \text {-UTR of PTEN } \\
\text { Reducing the mRNA level of PTEN } \\
\text { Promoting growth and metastatic features }\end{array}$ & [176] \\
\hline miRNA-205 & PTEN/Akt/mTOR & $\begin{array}{c}\text { PTEN inhibition } \\
\text { Activating Akt / mTOR signaling } \\
\text { Increasing malignancy of lung cancer cells }\end{array}$ & [177] \\
\hline miRNA-183-5p & PTEN/Akt/p53 & $\begin{array}{c}\text { Exerting oncogenic role } \\
\text { Promoting Akt phosphorylation via PTEN downregulation } \\
\text { Activating p53 }\end{array}$ & [178] \\
\hline
\end{tabular}




\subsection{MicroRNAs and PTEN Induction}

\subsubsection{Breast Cancer}

miRNAs capable of promoting PTEN expression are considered as a tumor-suppressing factor in breast cancer. To date, most of the studies have focused on revealing the role of tumor-promoting miRNAs in breast cancer progression. However, a newly published experiment has investigated the efficacy of miRNA-424-5p in breast cancer therapy. This tumor-suppressing miRNA diminishes colony formation, cell viability, and the proliferation of breast cancer cells, and it induces apoptosis. In this way, miRNA-424-5p promotes PTEN expression to downregulate PI3K/Akt/mTOR signaling, resulting in breast cancer suppression (Figure 2) [179]. However, we still have a long way in revealing the role of miRNAs in suppressing PTEN expression.

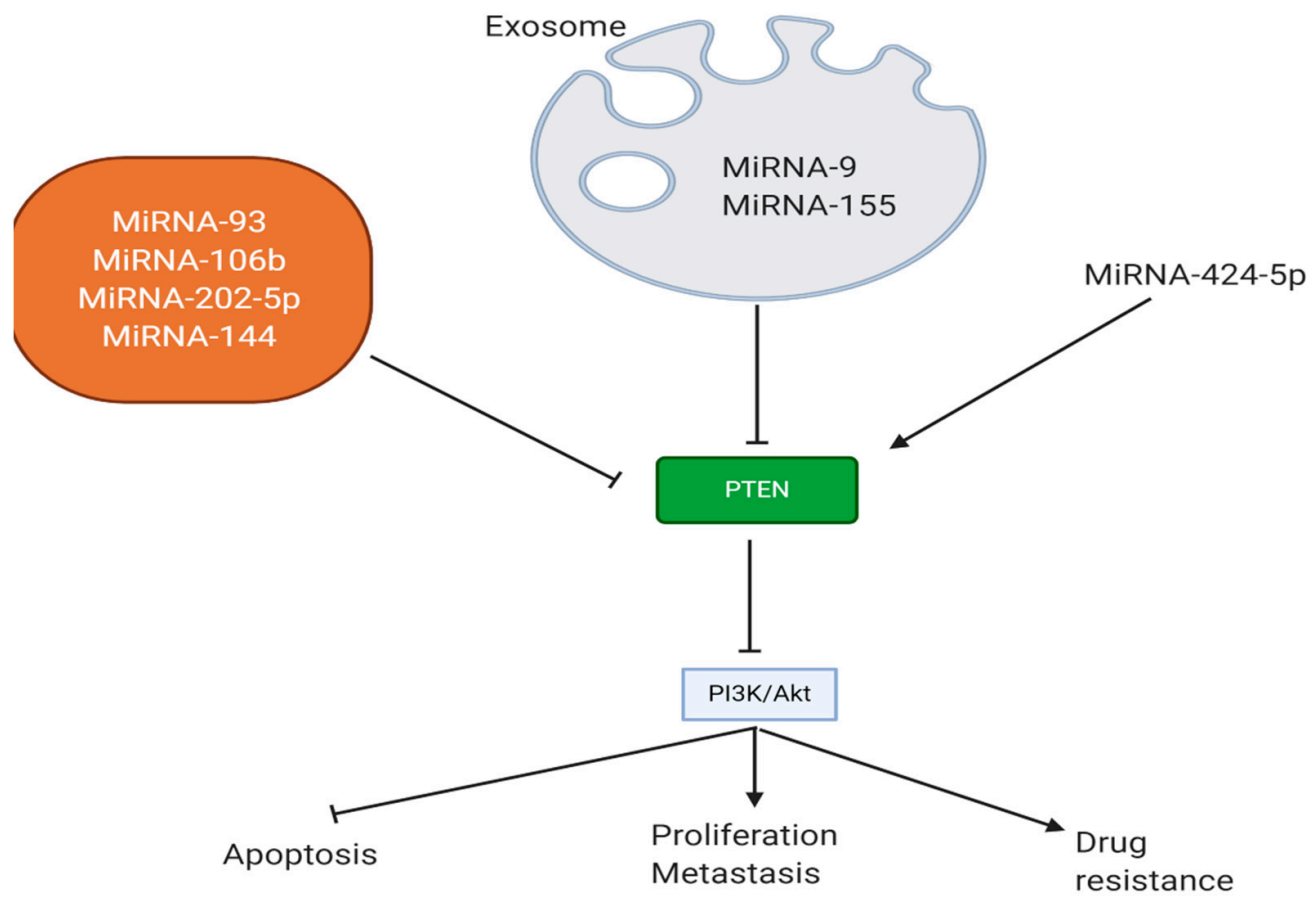

Figure 2. miRNAs suppressing/inducing PTEN expression in breast cancer, and affecting the progression, viability, and response of cancer cells to therapy.

\subsubsection{Lung Cancer}

In lung cancer cells, PTEN induction is a negative factor for proliferation and metastasis. miRNA-4299 is a new emerging miRNA in lung cancer that is capable of promoting PTEN expression. The downregulation of miRNA-4299 occurs in lung cancer cells, and it is associated with TNM stage, histological grade, and lymph node metastasis. Enhancing miRNA-4299 expression is associated with good prognosis and can suppress the proliferation and migration of lung cancer cells via PTEN upregulation and the subsequent inhibition of PI3K/Akt signaling [180]. miRNA-130 is another important miRNA in lung cancer, but its exact role has not been completely understood. It has been reported that miRNA-130 can function as a tumor-promoting factor via inducing enhancer of zeste homolog 2 (EZH2) expression [181], while another study focuses on the tumor-suppressing role of miRNA-130 in lung cancer, showing that it can induce apoptosis in lung cancer cells and impair their proliferation via PTEN upregulation [182]. Similar to breast cancer, most studies have focused on revealing the role of tumor-promoting miRNAs in PTEN inhibition, and more studies are needed in the identification of miRNAs inducing PTEN signaling in lung cancer suppression (Figure 3). 


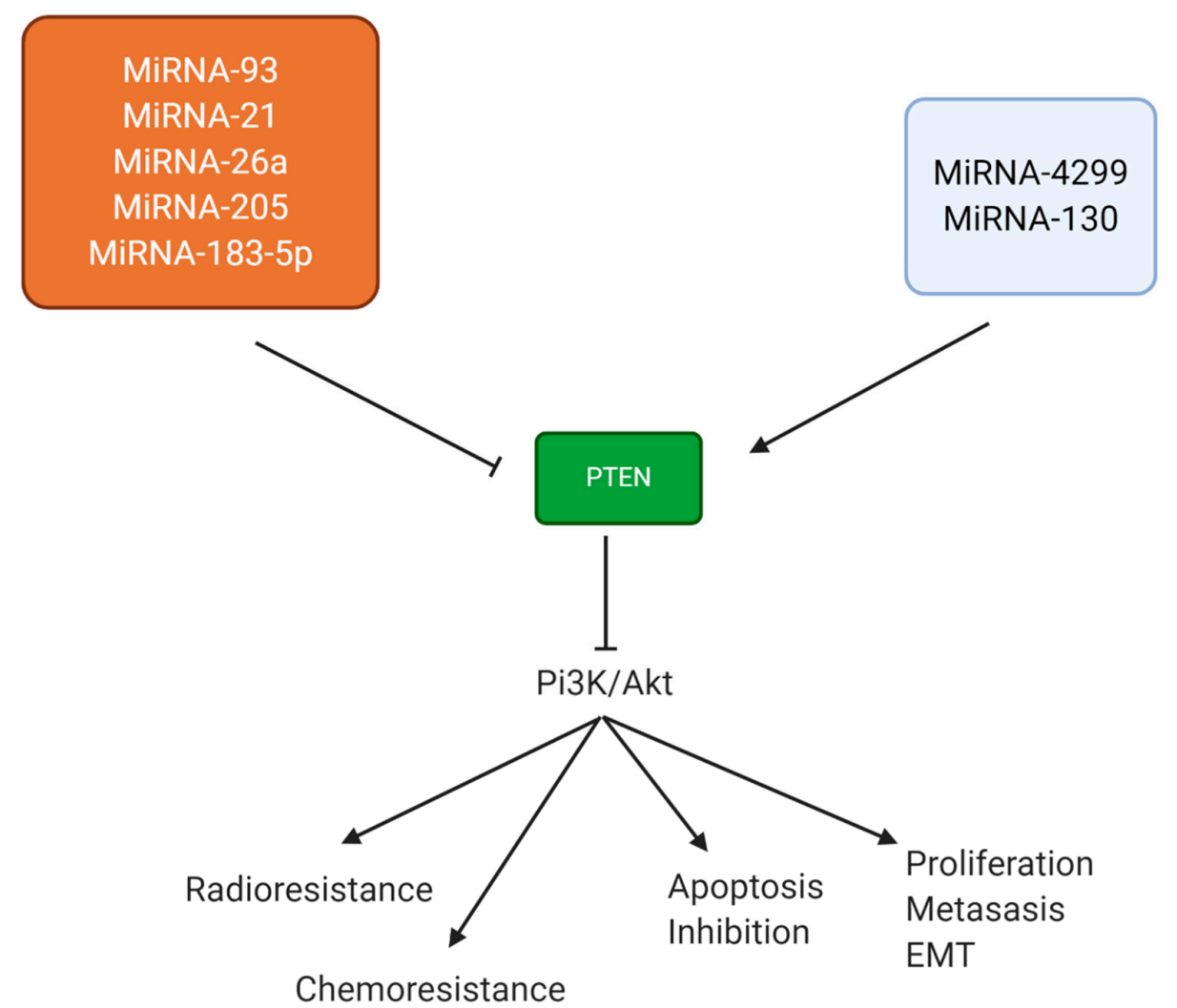

Figure 3. Radioresistance, chemoresistance, apoptosis, and metastasis of lung cancer cells are mainly affected by the miRNA/PTEN axis.

\subsection{MicroRNAs, PTEN, and Chemotherapy}

\subsubsection{Breast Cancer}

One of the preferred strategies in breast cancer therapy is chemotherapy. However, research is not always in favor, and increasing evidence demonstrates the capability of breast cancer cells to develop chemoresistance [183-188]. miRNAs have demonstrated a potential contribution in breast cancer chemoresistance. miRNA-30c triggers chemoresistance in breast cancer cells via histone deacetylase 9 (HDAC9) upregulation [189]. On the other hand, tumor-suppressor miRNAs such as miRNA-200c-3p are downregulated by lncRNA X-inactive specific transcript (XIST) in mediating chemoresistance [190]. miRNA-222 is suggested to be involved in inducing chemoresistance in breast cancer cells via affecting PTEN. The overexpression of miRNA-222 is associated with PTEN downregulation, paving the way for Akt upregulation and subsequent inhibition of $\mathrm{p} 27^{\mathrm{kip} 1}$. This axis provides Adriamycin resistance in breast cancer cells [191]. This signaling network is more complicated when it is found that Akt can affect more down-stream targets. Akt is capable of activating NF-kB via phosphorylating IkB kinase (IKK) [192-195]. NF-kB can induce cyclooxygenase2 (COX-2) expression, which is an obvious finding in different malignancies [196-199]. As tumor-promoting factors, miRNA-222 and miRNA-221 reduce PTEN expression to elevate stem-cell properties and the proliferation of breast cancer cells. PTEN inhibition results in Akt activation, upregulating NF-kB and inducing COX-2, which are of importance for enhancing breast cancer malignancy [140].

In addition to COX-2, FOXO family members can be affected by Akt. FOXO1, FOXO3, and FOXO4 are members of the FOXO transcription family. Akt is capable of phosphorylating FOXO1 to provide the translocation of FOXO1 at the route of nucleus to cytoplasm, where it is degraded by the ubiquitin-proteasome pathway [200,201]. Upon PTEN activation, the expression of Akt is inhibited, and FOXO1 enters the nucleus, where it induces cell cycle arrest and apoptosis [202]. Such interactions are important for the drug resistance of breast cancer cells. It has been reported that miRNA-222 as a tumor-promoting factor 
triggers Akt phosphorylation via PTEN downregulation. This leads to a decrease in FOXO1 expression and level in the nucleus, which is of importance for enhancing chemoresistance in breast cancer cells [203]. Several experiments were discussed examining the role of miRNA-222 in triggering chemoresistance in breast cancer cells. Now, it is completely obvious that miRNA-222 is tumor-promoting in breast cancer, and it can promote proliferation and chemoresistance [204]. It can be concluded that the expression of tumor-promoting miRNAs such as miRNA-19 undergo upregulation in drug-resistant breast cancer cells, while a decrease occurs in PTEN expression [205].

One of the interesting points of drug resistance is the relationship between factors regulating the proliferation and metastasis of cancer cells. It seems that when tumorsuppressing factors regulating cancer proliferation are downregulated, the way for the upregulation of metastatic factors is paved. Such association has been investigated in the drug resistance of breast cancer cells. It has been reported that EMT induction can trigger the chemoresistance of cancer cells [206-208]. In breast cancer cells, miRNA93 demonstrates an increase in expression that mediates the downregulation of PTEN, resulting in EMT induction and subsequent obtaining of drug resistance [209]. Although just one study has evaluated the EMT and PTEN relationship and their regulation by miRNAs in the drug resistance of breast cancer cells, we have still a long way in the identification of more miRNAs. For instance, p53 is a apoptosis-related factor that can function as an upstream mediator of PTEN in cancer therapy [210]. The combination of anti-miRNA-222/221 with cisplatin induces p53 expression to stimulate PTEN, resulting in increased efficacy in the eradication of triple-negative breast cancer cells [211].

The tumor-promoting miRNAs reduce the expression of PTEN in inducing chemoresistance. It seems that PTEN downregulation is associated with the resistance of cancer cells to chemotherapy-mediated apoptosis. The underlying molecular pathways involved in this kind of chemoresistance have been revealed. miRNA-222 can promote the resistance of breast cancer cells to Adriamycin chemotherapy via PTEN downregulation and the subsequent induction of Akt, leading to p27 inhibition and decreasing apoptotic cell death [191]. A same strategy is followed by miRNA-202-5p in inducing doxorubicin resistance, so that this miRNA significantly diminishes PTEN expression to stimulate PI3K/Akt signaling, resulting in apoptosis inhibition and providing chemoresistance [107]. Hence, the application of anti-tumor compounds capable of inducing apoptosis can be considered as a promising strategy in chemosensitivity. Overall, miRNAs are divided into two major groups, inducers and inhibitors of PTEN, that affect the response of breast cancer cells to chemotherapy (Table 3) [212].

Table 3. miRNAs regulating PTEN signaling in breast cancer chemotherapy.

\begin{tabular}{|c|c|c|c|c|}
\hline miRNA & $\begin{array}{c}\text { Chemotherapeutic } \\
\text { Agent }\end{array}$ & $\begin{array}{c}\text { Impact on } \\
\text { Chemotherapy }\end{array}$ & Remarks & Refs. \\
\hline miRNA-93 & Doxorubicin & Resistance & $\begin{array}{c}\text { PTEN downregulation } \\
\text { EMT induction } \\
\text { Increasing cancer metastasis and malignancy }\end{array}$ & [209] \\
\hline miRNA-202-5p & Doxorubicin & Resistance & $\begin{array}{l}\text { Enhancing tumor volume and progression } \\
\text { Downregulating PTEN and subsequent induction of PI3K/Akt signaling }\end{array}$ & [107] \\
\hline miRNA-222 & Adriamycin & Resistance & $\begin{array}{c}\text { Activation of PI3K/Akt signaling via PTEN downregulation } \\
\text { Association with poor prognosis }\end{array}$ & [203] \\
\hline miRNA-222 & Adriamycin & Resistance & $\begin{array}{c}\text { PTEN downregulation } \\
\text { Inducing Akt signaling } \\
\text { P27 inhibition } \\
\text { Triggering the resistance of cancer cells to apoptosis }\end{array}$ & [191] \\
\hline $\begin{array}{l}\text { miRNA-222 } \\
\text { miRNA-29a }\end{array}$ & $\begin{array}{l}\text { Adriamycin } \\
\text { Doxorubicin }\end{array}$ & Resistance & $\begin{array}{l}\text { Overexpression in drug-resistant cancer cells } \\
\text { Association with PTEN downregulation }\end{array}$ & [204] \\
\hline miRNA-520h & Paclitaxel & Resistance & $\begin{array}{c}\text { Binding to OTUD3 and reducing its expression } \\
\text { PTEN inhibition } \\
\text { Paving the way for Akt induction }\end{array}$ & [212] \\
\hline $\operatorname{miRNA}-221 / 222$ & Cisplatin & Resistance & $\begin{array}{l}\text { Downregulation of miRNA-221/222 enhances cisplatin sensitivity } \\
\text { Activation of p53/PTEN signaling following miRNA inhibition }\end{array}$ & [211] \\
\hline
\end{tabular}




\subsubsection{Lung Cancer}

Due to the malignant behavior of lung cancer cells in terms of proliferation and metastasis, they can obtain resistance to chemotherapy [213]. Increasing evidence demonstrates the role of miRNAs in lung cancer cells acquiring chemoresistance [214,215]. Furthermore, PTEN downregulation occurs in drug-resistant lung cancer cells [216,217]. In this section, the association of miRNA with PTEN signaling in regulating the response of lung cancer cells to chemotherapy is discussed.

Cisplatin resistance is an increasing challenge in the treatment of lung cancer $[218,219]$. Autophagy as a "self-digestion" mechanism is suggested to be involved in the chemoresistance of lung cancer cells [220-224]. miRNA-181 as a tumor-suppressing factor inhibits autophagy via light chain-3 (LC3) and autophagy-related gene 5 (ATG5) downregulation. This is mediated via PTEN upregulation and the subsequent inhibition of PI3K/Akt signaling [225]. However, autophagy can also sensitize lung cancer cells to chemotherapy $[226,227]$. This dual role of autophagy and its association with the miRNA/PTEN axis can be considered in further experiments. Apoptosis induction and impairing proliferation are two major pathways followed by miRNAs inducing PTEN in providing the cisplatin sensitivity of lung cancer cells [228].

In enhancing the chemosensitivity of lung cancer cells, silencing the expression of tumor-promoting miRNAs is of importance. It has been reported that miRNA-23a downregulation paves the way for erlotinib sensitivity via PTEN upregulation. Upon PTEN activation, PI3K/Akt signaling inhibition occurs, impairing lung cancer progression [229]. miRNA-21 is one of the most important miRNAs in lung cancer, and its association with chemoresistance has been investigated in several studies. Increasing evidence demonstrates miRNA-21 involvement in enhancing cancer proliferation and metastasis via inducing molecular pathways such as Akt and matrix metalloproteinases (MMPs). Anti-tumor compounds such as sinomenine reduce miRNA-21 expression in disrupting lung cancer progression $[230,231]$. By PTEN downregulation, miRNA-21 promotes the expression of Akt and extracellular-signal regulated kinase (ERK) pathways, leading to the gefitinib resistance of lung cancer cells [232]. Upon hypoxic conditions, exosomal transfer of miRNA-21 occurs that subsequently mediates the resistance of lung cancer cells to cisplatin chemotherapy [233]. So, the most important pathway that miRNA-21 follows in inducing the chemoresistance of lung cancer cells is PTEN downregulation and the subsequent induction of PI3K/Akt signaling [234,235].

miRNA-1269b is a new emerging miRNA in cancer with an oncogene role, and it is capable of increasing cancer growth and invasion via Akt phosphorylation [236]. Cisplatinresistant lung cancer cells demonstrate an increase in the expression of miRNA-1269b. An examination of molecular pathways shows that miRNA-1269b enhances cancer proliferation in vitro and in vivo and is correlated with chemoresistance. For this purpose, miRNA-1269b reduces PTEN expression to induce PI3K/Akt signaling [237]. The PTEN downregulation by miRNAs occurs via binding to $3^{\prime}$-UTR [238]. Interestingly, the proliferation and metastasis of cancer cells are in close relationship with each other and can trigger chemoresistance [239-241]. It has been reported that TGF- $\beta$ can induce EMT in mediating chemoresistance [242-245]. miRNA-134/487b/655 stimulates TGF- $\beta$-mediated EMT in lung cancer cells. Then, the downregulation of membrane-associated guanylate kinase, WW, and PDZ domain-containing protein 2 (MAGI2) occurs, leading to PTEN loss and the gefitinib resistance of lung cancer cells [246]. Overall, studies are in agreement with the role of the miRNA/PTEN axis in regulating the response of lung cancer cells to chemotherapy (Table 4) [247,248]. 
Table 4. miRNAs affecting the response of lung cancer cells to chemotherapy.

\begin{tabular}{|c|c|c|c|c|}
\hline miRNA & $\begin{array}{c}\text { Chemotherapeutic } \\
\text { Agent }\end{array}$ & $\begin{array}{c}\text { Effect on } \\
\text { Chemotherapy }\end{array}$ & Remarks & Refs. \\
\hline miRNA-181 & Cisplatin & Sensitivity & $\begin{array}{c}\text { PTEN upregulation } \\
\text { Inhibition of PI3K/Akt/mTOR signaling } \\
\text { Apoptosis induction } \\
\text { Disrupting cancer metastasis }\end{array}$ & [249] \\
\hline miRNA-29b-3p & Cisplatin & Sensitivity & $\begin{array}{c}\text { Disrupting cell viability } \\
\text { Reducing proliferation } \\
\text { Inducing apoptosis via Bax upregulation } \\
\text { Triggering PTEN signaling }\end{array}$ & [228] \\
\hline miRNA-23a & Erlotinib & Resistance & $\begin{array}{l}\text { Silencing miRNA-23a restores PTEN expression to suppress PI3K/Akt } \\
\text { signaling, leading to erlotinib sensitivity }\end{array}$ & [229] \\
\hline miRNA-134/487b/655 & Gefitinib & Resistance & $\begin{array}{c}\text { Inducing TGF-b1 signaling in reducing PTEN expression } \\
\text { Enhancing cancer metastasis via EMT induction } \\
\text { Providing chemoresistance }\end{array}$ & [246] \\
\hline miRNA-21 & Gefitinib & Resistance & $\begin{array}{l}\text { Reverse relationship between miRNA-21 and PTEN } \\
\text { Activation of Akt and ERK signaling pathways } \\
\text { Association with poor prognosis }\end{array}$ & [232] \\
\hline miRNA-21 & Cisplatin & Resistance & $\begin{array}{l}\text { Hypoxia induces exsoaomal transfer of miRNA-21 } \\
\text { Exerting PTEN inhibition }\end{array}$ & [233] \\
\hline miRNA-92b & Cisplatin & Resistance & $\begin{array}{l}\text { Establishing cancer proliferation } \\
\text { Reducing sensitivity to chemotherapy } \\
\text { PTEN inhibition }\end{array}$ & [248] \\
\hline miRNA-1269b & Cisplatin & Resistance & $\begin{array}{c}\text { Enhancing cancer cell growth } \\
\text { Apoptosis inhibition } \\
\text { Inducing PI3K/ Akt signaling via PTEN downregulation }\end{array}$ & [237] \\
\hline miRNA-21 & EGFR-TKI & Resistance & $\begin{array}{l}\text { Negative association with PTEN expression } \\
\text { Triggering PI3K/Akt signaling } \\
\text { Reducing chemosensitivity }\end{array}$ & [234] \\
\hline
\end{tabular}

\subsection{Regulation of microRNA/PTEN Axis}

\subsubsection{Breast Cancer}

As miRNAs can regulate PTEN expression in breast cancer, and this is of importance in cancer proliferation and invasion as well as response of cancer cells to chemotherapy, experiments have focused on revealing the role of upstream mediators regulating the miRNA/PTEN axis in breast cancer cells.

lncRNAs are an important part of ncRNAs with a length more than 200 nucleotides capable of regulating miRNAs in breast cancer [250]. Furthermore, lncRNAs regulate PTEN in affecting the proliferation and metastasis of breast cancer cells [251,252]. LncRNA PTENP1 is a tumor-promoting factor in breast cancer that not only affects breast cancer progression but also influences drug sensitivity. LncRNA PTENP1 reduces PTEN expression via miRNA-20a sponging to upregulate PI3K/Akt signaling, resulting in breast cancer proliferation, metastasis, and adriamycin resistance [253]. In reducing the expression of miRNAs, lncRNAs can function as competing endogenous RNA (ceRNA). Although previous study demonstrated a tumor-promoting role of PTENP1 in breast cancer, another study reveals the tumor-suppressing role of this important lncRNA. LncRNA PTENP1 upregulates PTEN expression by miRNA-19b inhibition via sponging. Then, Akt downregulation and p53 upregulation occur to restrict the proliferation and metastasis of breast cancer cells [171]. It seems that lncRNA PTENP1 functions as a double-edged sword in breast cancer, and its exact role is not certain. However, it can effectively regulate breast cancer progression via affecting the miRNA/PTEN axis [254]. By the identification of tumor-promoting lncRNAs, they can be targeted in further studies for suppressing breast cancer progression. For instance, lncRNA GAS5 triggers tamoxifen resistance via miRNA222 sponging and the subsequent inhibition of PTEN. Silencing GAS5 impairs breast cancer progression and enhances their sensitivity via activating the miRNA-222/PTEN axis [255]. To date, studies have focused on the recognition of tumor-promoting lncRNAs such as HOXC13-AS and ZFAS1, and further studies can identify tumor-suppressing lncRNAs regulating the miRNA/PTEN axis. It is obvious that (A) tumor-suppressing miRNAs are downregulated by lncRNAs in breast cancer progression, (B) PTEN downregulation occurs, 
(C) the way is paved for inducing factors involved in breast cancer malignancy such as PI3K/Akt, (D) breast cancer cells promote their proliferation and invasion, and (E) finally, they can obtain resistance to chemotherapy $[36,256]$.

It is worth mentioning that in addition to lncRNAs, circular RNAs (circRNAs) can regulate the miRNA/PTEN axis in breast cancer cells. To date, two studies have evaluated the regulatory impact of circRNAs on the miRNA/PTEN axis in breast cancer cells that are included here. CircSLC8A1 is an inhibitor of cancer progression by regulating miRNAs and enhancing PTEN in bladder cancer therapy [257]. This circRNA exerts anti-tumor activity in breast cancer cells. By sponging miRNA-671, circSLC8A1 activates PTEN expression to inhibit PI3K/Akt signaling, limiting breast cancer progression [258]. Similar to lncRNAs, circRNAs reduce the expression of target miRNAs via sponging. This provides the condition for the activation of PTEN signaling and subsequent inhibition in the proliferation and invasion of breast cancer cells [259].

In addition to lncRNAs and circRNAs, other molecular pathways can function as upstream mediators of the miRNA/PTEN axis in breast cancer cells. Tumor necrosis factorrelated apoptosis-inducing ligand (TRAIL) is a member of the tumor necrosis family (TNF) family that is capable of inducing apoptosis in cancer cells and is a promising target in cancer therapy [260]. However, it has been reported that cancer cells can obtain resistance to TRAIL-mediated apoptosis [261]. It seems that TRAIL resistance can trigger EMT in breast cancer cells to promote their metastasis and malignancy. In TRAIL-resistant cancer cells, miRNA-221 undergoes upregulation that subsequently reduces the expression of PTEN [262]. This study is also in line with previous experiments showing that the proliferation and invasion of breast cancer cells are in close relationship and the miRNA/PTEN axis plays a significant role. One of the hallmarks of cancer is the tumor microenvironment. Cancer-associated fibroblasts (CAFs) are the main stromal components of cancer cells with a potential role in cancer progression [190,263-265]. In breast cancer cells, CAFs can secrete exosomes containing miRNA-22 to bind to PTEN, reducing its expression and mediating tamoxifen resistance [266]. Therefore, upstream mediators of the miRNA/PTEN axis should be considered in breast cancer cells for developing novel therapeutics $[267,268]$.

\subsubsection{Lung Cancer}

One of the well-known tumor-suppressing lncRNAs in lung cancer is growth arrestspecific transcript 5 (GAS5). Enhancing the expression of lncRNA GAS5 effectively disrupts the proliferation and migration of lung cancer cells via miRNA-205 downregulation and enhancing PTEN expression [269]. It is noteworthy that lncRNA GAS5 can regulate the response of lung cancer cells to chemotherapy via modulating the miRNA/PTEN axis. For this purpose, lncRNA GAS5 reduces miRNA-21 expression to induce PTEN signaling [270]. Increasing evidence demonstrates that lung cancer cells, due to their aggressiveness and uncontrolled proliferation and metastasis, can obtain resistance to radiotherapy. The potential of GAS5 in providing radiosensitivity has been evaluated. By reducing miRNA-21 expression, lncRNA GAS5 induces apoptosis in lung cancer cells exposed to radiotherapy. It seems that PTEN upregulation and the subsequent inhibition of Akt signaling play a significant role in this case [271]. In contrast, tumor-promoting lncRNAs promote lung cancer progression via regulating the miRNA/PTEN axis. LncRNA LEF1-AS1 undergoes upregulation in lung cancer patients. This lncRNA promotes miRNA-221 expression to inhibit PTEN signaling, leading to proliferation inhibition and apoptosis induction in lung cancer cells [272]. Therefore, the identification of lncRNAs regulating the miRNA/PTEN axis can be of importance in developing novel therapeutics in lung cancer therapy $[252,266]$. One of the hallmarks of cancer cells is their alteration in metabolism. In order to meet their high need for energy, they utilize glycolysis [273]. CircRNAs can regulate the miRNA/PTEN axis in targeting the glucose uptake and metabolism of lung cancer cells. CircLARP4 reduces miRNA-135b expression to induce PTEN signaling. Then, it inhibits the Akt/HIF-1a axis to induce apoptosis in lung cancer cells and impair glycolysis [274]. 
NF-kB signaling is a regulator of biological mechanisms, mainly the immune system, and it can induce inflammation in promoting cancer progression [275-277]. Targeting and suppressing NF-kB signaling can significantly reduce lung cancer viability and proliferation [278-282]. It has been reported that NF-kB promotes miRNA-548as-3p expression to induce PTEN downregulation. Then, the way is paved for PI3K/Akt induction to promote the proliferation of lung cancer cells [283]. However, we are still at the beginning point, and more studies will reveal upstream mediators of the miRNA/PTEN axis [284].

\subsection{MicroRNA/PTEN Axis: A Target of Anti-Tumor Compounds}

\subsubsection{Breast Cancer}

One of the interesting points of the miRNA/PTEN axis is its targeting by anti-tumor compounds. Most of the anti-tumor compounds evaluated in breast cancer therapy are phytochemicals targeting the miRNA/PTEN axis. In this section, we provide a mechanistic discussion of the role of naturally occurring compounds with anti-tumor activity in regulating the miRNA/PTEN axis.

Curcumin is a plant derived-natural compound derived from Curcuma longa with anti-tumor activity against breast cancer cells capable of inducing apoptosis and suppressing metastasis [285-290]. Curcumin is an important regulator of cell cycle in cancer. It seems that curcumin administration can mainly result in cell cycle arrest of cancer cells in the G2/M phase [291,292]. Curcumin can induce apoptosis in cancer cells via activating caspase cascade and upregulating caspase-3 expression [293]. It has been reported that curcumin can regulate miRNA expression in cancer therapy [294-296]. Upon curcumin administration, the expression level of tumor-promoting miRNAs including miRNA-21 and miRNA-27a undergoes downregulation, while an increase occurs in the expression of tumor-suppressing miRNAs such as miRNA-22 and miRNA-145 [297]. As PI3K/Akt activation is a common finding in cancer, it has been reported that curcumin administration downregulates PI3K/Akt expression via inducing PTEN signaling [298]. Curcumin can suppress the progression of chemoresistant-cancer cells via enhancing PTEN expression [299]. Curcumin administration suppresses breast cancer proliferation and stimulates cell cycle arrest at the G1/S phase. Mechanistically, curcumin downregulates the expression of miRNA-19a and miRNA-19b to induce PTEN signaling, leading to Akt downregulation and providing conditions for breast cancer therapy [300]. It seems that curcumin exerts its anti-tumor activity in a time- and dose-dependent manner. Exposing breast cancer cells to curcumin is correlated with miRNA-21 downregulation, the subsequent induction of PTEN, and the upregulation of caspase-3/9 in impairing breast cancer progression [301]. The important downstream target that is affected by the miRNA/PTEN axis is PI3K/Akt signaling. For this purpose, thidiazuron activates the miRNA-202-5p/PTEN axis to suppress PI3K/Akt signaling, leading to breast cancer inhibition [302].

Cantharidin (CTD) is a well-known compound in traditional Chinese medicine that can suppress cancer proliferation via triggering DNA damage [303]. It can induce apoptosis in cancer cells and reverse chemoresistance [304,305]. In breast cancer cells, CTD inhibits cancer progression in a time-dependent manner. CTD decreases the expression of miRNA160b-93 as a tumor-promoting factor to enhance the expression of its downstream target PTEN, resulting in breast cancer inhibition [306]. Matrine is also an alkaloid derived from Sophora flavescens with capability in regulating the expression of miRNAs in cancer therapy [307]. It is noteworthy that it has been reported that matrine can regulate the miRNA/PTEN axis in colorectal cancer therapy [231], which is the same strategy that is followed in breast cancer therapy. In a time- and dose-dependent manner, matrine reduces breast cancer proliferation and triggers cell cycle arrest at the G1/S phase. Via miRNA-21 inhibition, matrine promotes PTEN expression to induce Akt dephosphorylation, leading to an accumulation of Bad, p21 and p27 in breast cancer therapy [308].

Based on the published experiments, the following points can be concluded:

- Phytochemicals can be considered as epigenetic drugs in regulating miRNA expression,

- By targeting miRNAs, natural compounds can modulate PTEN expression, 
- $\quad$ PTEN upregulation can impair PI3K/Akt signaling as the important pathway required for cancer progression,

- Apoptosis induction and proliferation inhibition are the major outcomes of using phytochemicals targeting the miRNA/PTEN axis in breast cancer therapy (Figure 4) [309-313].

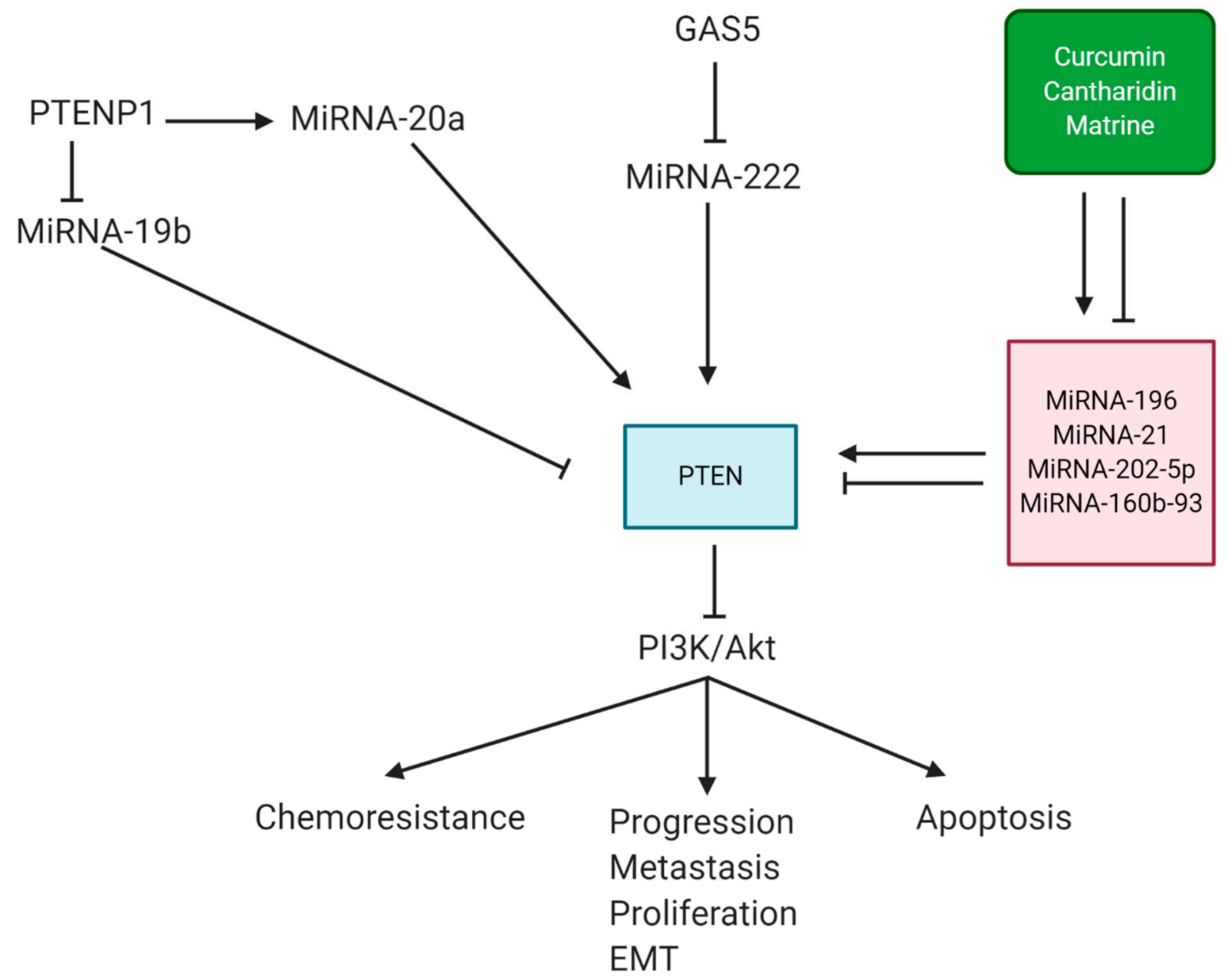

Figure 4. Anti-tumor compounds such as curcumin, cantharidin, and matrin target miRNAs in affecting the PTEN/PI3K/Akt axis in breast cancer therapy. Long non-coding RNAs (LncRNAs) such as PTENP1 and growth arrestspecific transcript 5 (GAS5) function as the main upstream mediators of the miRNA/PTEN axis in breast cancer.

\subsubsection{Lung Cancer}

Similar to breast cancer, anti-tumor compounds can regulate the miRNA/PTEN axis in affecting lung cancer progression. In this way, the expression of tumor-suppressing miRNAs undergoes downregulation, while an increase occurs in the expression of tumorpromoting miRNAs. Triptolide is a potent anti-tumor agent that has demonstrated inhibitory effect on cancer progression via targeting molecular pathways. Triptolide administration impairs the metastasis of lung cancer cells via EMT inhibition and reducing the expression levels of matrix metalloproteinase-9 (MMP9) [314]. This plant-derived natural compound induces apoptosis in lung cancer cells via miRNA-204-5p upregulation and the subsequent inhibition of Akt signaling [315]. In enhancing PTEN expression, triptolide promotes miRNA-21 expression to induce apoptosis in lung cancer cells, impairing their proliferation and viability [316]. The regulation of the miRNA/PTEN axis by antitumor compounds is of importance in enhancing the chemosensitivity of lung cancer cells. Baicalein administration is correlated with the cisplatin sensitivity of lung cancer cells via miRNA-424-3p downregulation, subsequent induction of PTEN signaling, and a significant decrease in PI3K/Akt expression [317]. As miRNAs are considered as key players in 
cisplatin resistance [318], their modulation by anti-tumor compounds paves the way for sensitivity. Exposing lung cancer cells to lidocaine induces miRNA-21 downregulation to promote PTEN expression, leading to PI3K/Akt suppression and cisplatin sensitivity [319]. One of the interesting points is the anti-tumor activity of propofol as an anesthetic agent. This compound is exclusively applied in cancer therapy, and it is capable of regulating different molecular pathways in cancer therapy, particularly miRNAs [320-322]. In non-small cell lung cancer, propofol downregulates miRNA-21 expression to induce apoptosis in a time- and dose-dependent manner. Upon miRNA-21 inhibition, propofol increases PTEN expression, which mediates anti-tumor activity against lung cancer cells [323]. Although a few studies have evaluated miRNA/PTEN axis regulation by anti-tumor compounds, it seems that this pathway is a novel target for impairing lung cancer growth (Figure 5) [324].

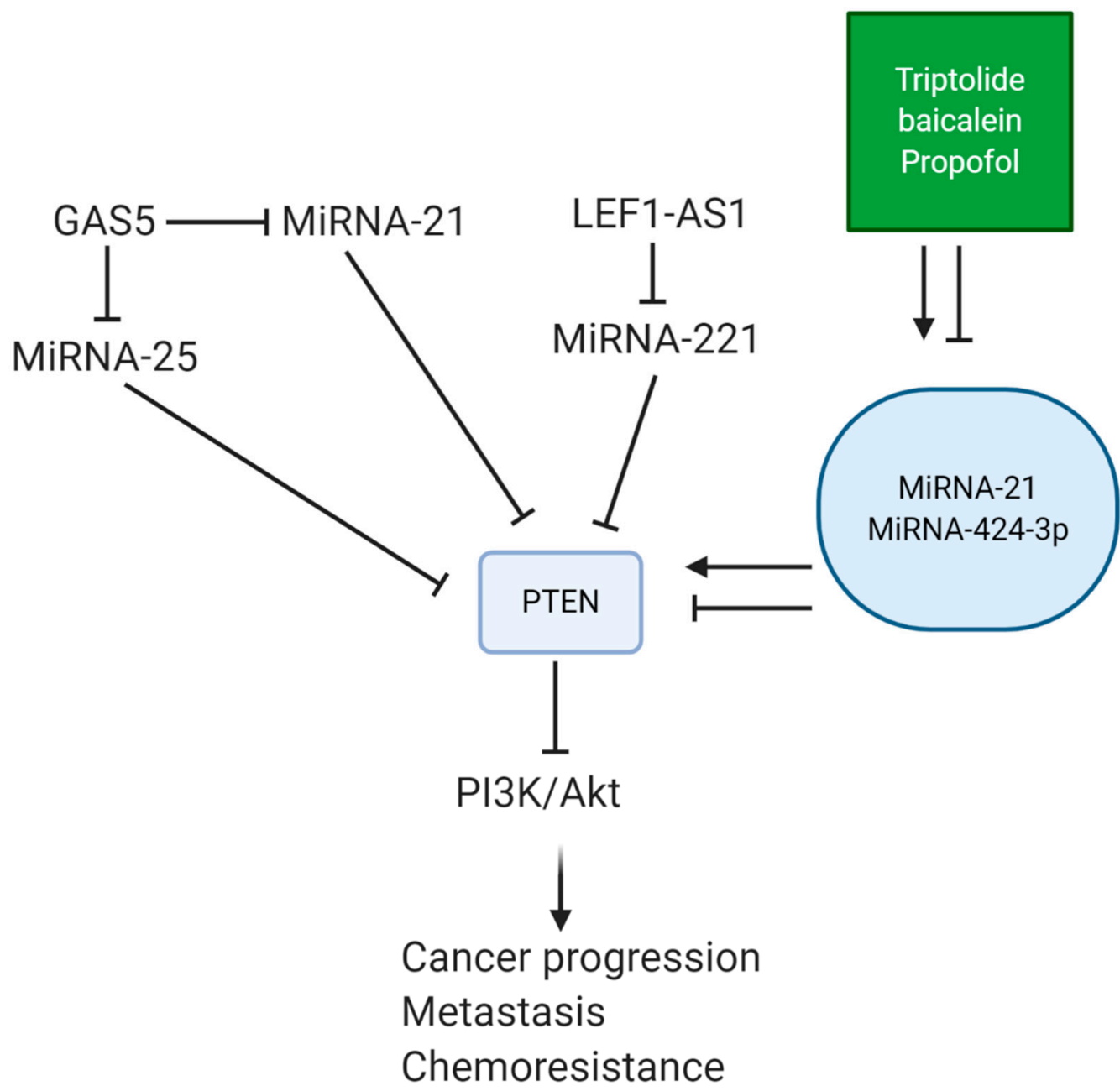

Figure 5. Similar to breast cancer, anti-tumor compounds and lncRNAs can regulate the miRNA/PTEN axis in affecting the progression of lung cancer cells.

\section{Conclusions and Remarks}

In the present review, a mechanistic discussion of miRNA and PTEN interaction in lung and breast cancers was provided. We investigated this interaction in lung and breast cancers as the most malignant thoracic tumors. The results were in line with each other. PTEN loss occurs in both lung and breast cancers, leading to their progression via the activation of PI3K/Akt signaling, and downstream targets including EMT, GSK-3b, HIF-1a, and so on. miRNAs are divided into two main categories, including tumor-suppressing miRNAs that promote PTEN expression and tumor-promoting miRNAs that reduce PTEN expression. Furthermore, the miRNA/PTEN axis can be regulated by upstream mediators 
and anti-tumor compounds. LncRNAs and circRNAs are the most well-known regulators of the miRNA/PTEN axis in lung and breast cancers. Anti-tumor compounds promote the expression of tumor-suppressing miRNAs in inducing PTEN expression and suppressing cancer malignancy.

It is noteworthy that the expression of miRNA and PTEN as well as their interaction and capability of being used as diagnostic and prognostic factors in lung and breast cancers have been investigated. With respect to the fact that PTEN loss occurs in cancer patients, and miRNAs regulating PTEN have been identified, they can be used as reliable biomarkers. Novel therapeutics can be developed for application in clinical studies and treatment of lung and breast cancer patients. However, we are still at the beginning point, and more studies are needed to evaluate the miRNA/PTEN axis in these malignant tumors.

Author Contributions: M.A., H.K. and A.P.K. participated in designing the outline, title and collecting articles. Software works were performed by M.A. and A.Z. (Ali Zarrabi). A.J.A., M.H.G., S.M., F.H., A.Z. (Amirhossein Zabolian), M.E., K.H. and M.A. prepared the first draft. Critical editing was performed by H.K. and A.P.K. All authors have read and agreed to the published version of the manuscript.

Funding: This work was supported by grants from Singapore Ministry of Education [T2EP301200042], the National Research Foundation Singapore and the Singapore Ministry of Education under its Research Centre's of Excellence initiative to Cancer Science Institute of Singapore, National University of Singapore to A.P.K.

Institutional Review Board Statement: Not applicable.

Informed Consent Statement: Not applicable.

Data Availability Statement: Not applicable.

Acknowledgments: This work was supported by grants from Singapore Ministry of Education [T2EP30120-0042], the National Research Foundation Singapore and the Singapore Ministry of Education under its Research Centre's of Excellence initiative to Cancer Science Institute of Singapore, National University of Singapore to A.P.K.

Conflicts of Interest: The authors declare no conflict of interest.

Abbreviations: SCLC: small cell lung cancer; NSCLC, non-small cell lung cancer; miRNAs, microRNAs; TGF-b, transforming growth factor-beta; EMT, epithelial-to-mesenchymal transition; RERG, ras-related and estrogen-regulated growth inhibitor; SP1, specificity protein 1 ; MRP1, multidrug resistance protein 1; PTEN, phosphatase and tensin homolog; $3^{/}-\mathrm{UTR}, 3^{/}$-untranslated region; mRNA, messenger RNA; lncRNAs, long non-coding RNAs; circRNAs, circular RNAs; Akt, protein kinase B; PI3K, phosphatidylinositol 3-kinase; mTOR, mammalian target of rapamycin; PIP2, phosphatidylinositol-4,5-biphosphate; PIP3, phosphatidyilinositol-3,4,5-triphosphate; $\mathrm{PH}$, pleckstrin homology; NF-kB, nuclear factor-kappaB; CSCs, cancer stem cells; CICs, cancer-initiating cells; BCSCs, breast cancer stem cells; PAEs, phthalates; PCNA, proliferating cell nuclear antigen; Skp2, S-phase kinase-associated protein 2; HK2, hexokinase 2; PKM2, pyruvate kinase isozyme M2; PD-L1, programmed death-ligand 1; EZH2, enhancer of zeste homolog 2; HDAC9, histone deacetylase 9; IKK, IkB kinase; COX-2, cyclooxygenase-2; LC3, light chain-3; ATG5, autophagy-related gene 5; ceRNA, competing endogenous RNA; TRAIL, tumor necrosis factor-related apoptosis-inducing signal; CAFs, cancer associated fibroblasts; GAS5, growth arrest-specific transcript 5; CTD, cantharidin; MMP9, matrix metalloproteinase-9; CASC9, cancer susceptibility candidate 9; ERK, extracellular-signal regulated kinase; MMPs, matrix metalloproteinases; TNF, tumor necrosis factor; TNM, tumor node metastasis; XIST, X-inactive specific transcript.

\section{References}

1. Quintanal-Villalonga, Á.; Molina-Pinelo, S. Epigenetics of lung cancer: A translational perspective. Cellular Oncol. 2019, 1-18. [CrossRef] [PubMed]

2. Zhang, M.; Wang, B.; Chong, Q.Y.; Pandey, V.; Guo, Z.; Chen, R.M.; Wang, L.; Wang, Y.; Ma, L.; Kumar, A.P.; et al. A novel small-molecule inhibitor of trefoil factor 3 (TFF3) potentiates MEK1/2 inhibition in lung adenocarcinoma. Oncogenesis $2019,8,65$. [CrossRef] [PubMed] 
3. Lee, J.H.; Mohan, C.D.; Basappa, S.; Rangappa, S.; Chinnathambi, A.; Alahmadi, T.A.; Alharbi, S.A.; Kumar, A.P.; Sethi, G.; Ahn, K.S.; et al. The IкB Kinase Inhibitor ACHP Targets the STAT3 Signaling Pathway in Human Non-Small Cell Lung Carcinoma Cells. Biomolecules 2019, 9, 875. [CrossRef]

4. Torre, L.A.; Trabert, B.; DeSantis, C.E.; Miller, K.D.; Samimi, G.; Runowicz, C.D.; Gaudet, M.M.; Jemal, A.; Siegel, R.L. Ovarian cancer statistics, 2018. CA Cancer J. Clin. 2018, 68, 284-296. [CrossRef]

5. Bordoloi, D.; Banik, K.; Padmavathi, G.; Vikkurthi, R.; Harsha, C.; Roy, N.K.; Singh, A.K.; Monisha, J.; Wang, H.; Kumar, A.P.; et al TIPE2 Induced the Proliferation, Survival, and Migration of Lung Cancer Cells Through Modulation of Akt/mTOR/NF-kB Signaling Cascade. Biomolecules 2019, 9, 836. [CrossRef]

6. Jung, Y.Y.; Shanmugam, M.K.; Narula, A.S.; Kim, C.; Lee, J.H.; Namjoshi, O.A.; Blough, B.E.; Sethi, G.; Ahn, K.S. Oxymatrine Attenuates Tumor Growth and Deactivates STAT5 Signaling in a Lung Cancer Xenograft Model. Cancers 2019, 11, 49. [CrossRef]

7. Pio, R.; Montuenga, L.M. Alternative splicing in lung cancer. J. Thorac. Oncol. 2009, 4, 674-678. [CrossRef]

8. Lee, J.H.; Kim, C.; Lee, S.G.; Sethi, G.; Ahn, K.S. Ophiopogonin D, a Steroidal Glycoside Abrogates STAT3 Signaling Cascade and Exhibits Anti-Cancer Activity by Causing GSH/GSSG Imbalance in Lung Carcinoma. Cancers 2018, 10, 427. [CrossRef]

9. Yang, M.H.; Lee, J.H.; Ko, J.H.; Jung, S.H.; Sethi, G.; Ahn, K.S. Brassinin Represses Invasive Potential of Lung Carcinoma Cells through Deactivation of PI3K/Akt/mTOR Signaling Cascade. Molecules 2019, 24, 1584. [CrossRef] [PubMed]

10. Royal College of Physicians. National Lung Cancer Audit Annual Report 2017 (for the Audit Period 2016). Available online: https:/ / www.rcplondon.ac.uk/projects/outputs/nlca-annual-report-2017 (accessed on 18 February 2021).

11. Wang, L.; Syn, N.L.; Subhash, V.V.; Any, Y.; Thuya, W.L.; Cheow, E.S.H.; Kong, L.; Yu, F.; Peethala, P.C.; Wong, A.L.; et al. Pan-HDAC inhibition by panobinostat mediates chemosensitization to carboplatin in non-small cell lung cancer via attenuation of EGFR signaling. Cancer Lett. 2018, 417, 152-160. [CrossRef] [PubMed]

12. McKee, A.M.; Hall, L.J.; Robinson, S.D. The microbiota, antibiotics and breast cancer. Future Med. 2019. [CrossRef] [PubMed]

13. Wang, C.; Kar, S.; Lai, X.; Cai, W.; Arfuso, F.; Sethi, G.; Lobie, P.E.; Goh, B.C.; Lim, L.H.K.; Hartman, M.; et al. Triple negative breast cancer in Asia: An insider's view. Cancer Treat. Rev. 2018, 62, 29-38. [CrossRef]

14. Jia, L.Y.; Shanmugam, M.K.; Sethi, G.; Bishayee, A. Potential role of targeted therapies in the treatment of triple-negative breast cancer. Anti-Cancer Drugs 2016, 27, 147-155. [CrossRef]

15. Chen, L.; Yuan, Y.; Kar, S.; Kanchi, M.M.; Arora, S.; Kim, J.E.; Koh, P.F.; Yousef, E.; Samy, R.P.; Shanmugam, M.K.; et al. PPAR $\gamma$ Ligand-induced Annexin A1 Expression Determines Chemotherapy Response via Deubiquitination of Death Domain Kinase RIP in Triple-negative Breast Cancers. Mol. Cancer Ther. 2017, 16, 2528-2542. [CrossRef]

16. Shanmugam, M.K.; Ahn, K.S.; Hsu, A.; Woo, C.C.; Yuan, Y.; Tan, K.H.B.; Chinnathambi, A.; Alahmadi, T.A.; Alharbi, S.A.; Koh, A.P.F.; et al. Thymoquinone Inhibits Bone Metastasis of Breast Cancer Cells Through Abrogation of the CXCR4 Signaling Axis. Front. Pharmacol. 2018, 9, 1294. [CrossRef]

17. Ong, P.S.; Wang, L.; Chia, D.M.; Seah, J.Y.; Kong, L.R.; Thuya, W.L.; Chinnathambi, A.; Lau, J.Y.; Wong, A.L.; Yong, W.P.; et al. A novel combinatorial strategy using Seliciclib $\left({ }^{\circledR}\right)$ and Belinostat $\left({ }^{\circledR}\right)$ for eradication of non-small cell lung cancer via apoptosis induction and BID activation. Cancer Lett. 2016, 381, 49-57. [CrossRef]

18. Ong, M.S.; Cai, W.; Yuan, Y.; Leong, H.C.; Tan, T.Z.; Mohammad, A.; You, M.L.; Arfuso, F.; Goh, B.C.; Warrier, S.; et al. 'Lnc'-ing Wnt in female reproductive cancers: Therapeutic potential of long non-coding RNAs in Wnt signalling. Br. J. Pharmacol. 2017, 174, 4684-4700. [CrossRef]

19. Sun, H.; Sun, Y. Lidocaine inhibits proliferation and metastasis of lung cancer cell via regulation of miR-539/EGFR axis. Artif. Cells Nanomed. Biotechnol. 2019, 47, 2866-2874. [CrossRef] [PubMed]

20. Jiang, Z.; Zhang, J.; Chen, F.; Sun, Y. MiR-148b suppressed non-small cell lung cancer progression via inhibiting ALCAM through the NF-kB signaling pathway. Thorac Cancer 2020, 11, 415-425. [CrossRef] [PubMed]

21. Zhang, H.; Lang, T.Y.; Zou, D.L.; Zhou, L.; Lou, M.; Liu, J.S.; Li, Y.Z.; Ding, D.Y.; Li, Y.C.; Zhang, N.; et al. miR-520b Promotes Breast Cancer Stemness Through Hippo/YAP Signaling Pathway. Onco Targets Ther. 2019, 12, 11691-11700. [CrossRef]

22. Wu, J.; Miao, J.; Ding, Y.; Zhang, Y.; Huang, X.; Zhou, X.; Tang, R. MiR-4458 inhibits breast cancer cell growth, migration, and invasiveness by targeting CPSF4. Biochem. Cell Biol. 2019, 97, 722-730. [CrossRef]

23. Cai, Y.; Hao, Y.; Ren, H.; Dang, Z.; Xu, H.; Xue, X.; Gao, Y. miR-1305 Inhibits The Progression Of Non-Small Cell Lung Cancer By Regulating MDM2. Cancer Manag. Res. 2019, 11, 9529-9540. [CrossRef] [PubMed]

24. Luo, J.; Pan, J.; Jin, Y.; Li, M.; Chen, M. MiR-195-5p Inhibits Proliferation and Induces Apoptosis of Non-Small Cell Lung Cancer Cells by Targeting CEP55. Onco Targets Ther 2019, 12, 11465-11474. [CrossRef] [PubMed]

25. Chae, D.K.; Park, J.; Cho, M.; Ban, E.; Jang, M.; Yoo, Y.S.; Kim, E.E.; Baik, J.H.; Song, E.J. MiR-195 and miR-497 suppress tumorigenesis in lung cancer by inhibiting SMURF2-induced TGF- $\beta$ receptor I ubiquitination. Mol. Oncol. 2019, 13, 2663-2678. [CrossRef]

26. Wang, H.; Deng, Q.; Lv, Z.; Ling, Y.; Hou, X.; Chen, Z.; Dinglin, X.; Ma, S.; Li, D.; Wu, Y.; et al. N6-methyladenosine induced miR-143-3p promotes the brain metastasis of lung cancer via regulation of VASH1. Mol. Cancer 2019, 18, 181. [CrossRef]

27. Zou, P.; Zhu, M.; Lian, C.; Wang, J.; Chen, Z.; Zhang, X.; Yang, Y.; Chen, X.; Cui, X.; Liu, J.; et al. miR-192-5p suppresses the progression of lung cancer bone metastasis by targeting TRIM44. Sci. Rep. 2019, 9, 19619. [CrossRef]

28. Zhang, J.; Hua, X.; Qi, N.; Han, G.; Yu, J.; Yu, Y.; Wei, X.; Li, H.; Chen, X.; Leng, C.; et al. MiR-27b suppresses epithelialmesenchymal transition and chemoresistance in lung cancer by targeting Snail1. Life Sci. 2020, 254, 117238. [CrossRef]

29. Huang, L.; Tang, X.; Shi, X.; Su, L. miR-532-5p promotes breast cancer proliferation and migration by targeting RERG. Exp. Ther. Med. 2020, 19, 400-408. [CrossRef] [PubMed] 
30. Cai, F.; Chen, L.; Sun, Y.; He, C.; Fu, D.; Tang, J. MiR-539 inhibits the malignant behavior of breast cancer cells by targeting SP1. Biochem. Cell Biol. 2020, 98, 426-433. [CrossRef]

31. Hong, T.; Ding, J.; Li, W. miR-7 Reverses Breast Cancer Resistance To Chemotherapy By Targeting MRP1 And BCL2. Onco Targets Ther. 2019, 12, 11097-11105. [CrossRef] [PubMed]

32. Gao, Y.; Zhang, W.; Liu, C.; Li, G. miR-200 affects tamoxifen resistance in breast cancer cells through regulation of MYB. Sci. Rep. 2019, 9, 18844. [CrossRef]

33. Duan, W.J.; Bi, P.D.; Ma, Y.; Liu, N.Q.; Zhen, X. MiR-512-3p regulates malignant tumor behavior and multi-drug resistance in breast cancer cells via targeting Livin. Neoplasma 2020, 67, 102-110. [CrossRef]

34. Pasculli, B.; Barbano, R.; Rendina, M.; Fontana, A.; Copetti, M.; Mazza, T.; Valori, V.M.; Morritti, M.; Maiello, E.; Graziano, P.; et al. Hsa-miR-210-3p expression in breast cancer and its putative association with worse outcome in patients treated with Docetaxel. Sci. Rep. 2019, 9, 14913. [CrossRef]

35. Estevão-Pereira, H.; Lobo, J.; Salta, S.; Amorim, M.; Lopes, P.; Cantante, M.; Reis, B.; Antunes, L.; Castro, F.; Palma de Sousa, S.; et al. Overexpression of circulating MiR-30b-5p identifies advanced breast cancer. J. Transl. Med. 2019, 17, 435. [CrossRef] [PubMed]

36. Li, X.; Wang, Q.; Rui, Y.; Zhang, C.; Wang, W.; Gu, J.; Tang, J.; Ding, Y. HOXC13-AS promotes breast cancer cell growth through regulating miR-497-5p/PTEN axis. J. Cell Physiol. 2019, 234, 22343-22351. [CrossRef]

37. Yu, Y.; Cao, X.-C. miR-190-5p in human diseases. Cancer Cell Int. 2019, 19, 257. [CrossRef]

38. Ashrafizadeh, M.; Ang, H.L.; Moghadam, E.R.; Mohammadi, S.; Zarrin, V.; Hushmandi, K.; Samarghandian, S.; Zarrabi, A.; Najafi, M.; Mohammadinejad, R.; et al. MicroRNAs and Their Influence on the ZEB Family: Mechanistic Aspects and Therapeutic Applications in Cancer Therapy. Biomolecules 2020, 10, 1040. [CrossRef] [PubMed]

39. Ashrafizadeh, M.; Hushmandi, K.; Hashemi, M.; Akbari, M.E.; Kubatka, P.; Raei, M.; Koklesova, L.; Shahinozzaman, M.; Mohammadinejad, R.; Najafi, M.; et al. Role of microRNA/Epithelial-to-Mesenchymal Transition Axis in the Metastasis of Bladder Cancer. Biomolecules 2020, 10, 1159. [CrossRef]

40. Ashrafizadeh, M.; Zarrabi, A.; Hushmandi, K.; Hashemi, F.; Moghadam, E.R.; Owrang, M.; Hashemi, F.; Makvandi, P.; Goharrizi, M.A.S.B.; Najafi, M. Lung cancer cells and their sensitivity/resistance to cisplatin chemotherapy: Role of microRNAs and upstream mediators. Cell. Signal. 2020, 109871.

41. Kozomara, A.; Griffiths-Jones, S. miRBase: Integrating microRNA annotation and deep-sequencing data. Nucleic Acids Res. 2010, 39, 152-157. [CrossRef] [PubMed]

42. Witten, L.; Slack, F.J. miR-155 as a novel clinical target for hematological malignancies. Carcinogenesis 2020, 41, 2-7. [CrossRef] [PubMed]

43. Liu, H.P.; Zhang, Y.; Liu, Z.T.; Qi, H.; Zheng, X.M.; Qi, L.H.; Wang, J.Y. MiR-203 regulates proliferation and apoptosis of ovarian cancer cells by targeting SOCS3. Eur. Rev. Med. Pharmacol Sci. 2019, 23, 9286-9294.

44. Hu, Z.; Cai, M.; Zhang, Y.; Tao, L.; Guo, R. miR-29c-3p inhibits autophagy and cisplatin resistance in ovarian cancer by regulating FOXP1/ATG14 pathway. Cell Cycle 2020, 19, 193-206. [CrossRef]

45. Han, Z.; Zhan, R.; Chen, S.; Deng, J.; Shi, J.; Wang, W. miR-181b/Oncostatin m axis inhibits prostate cancer bone metastasis via modulating osteoclast differentiation. J. Cell Biochem. 2020, 121, 1664-1674. [CrossRef]

46. Wu, Q.; Zhong, H.; Jiao, L.; Wen, Y.; Zhou, Y.; Zhou, J.; Lu, X.; Song, X.; Ying, B. MiR-124-3p inhibits the migration and invasion of Gastric cancer by targeting ITGB3. Pathol. Res. Pract. 2020, 216, 152762. [CrossRef] [PubMed]

47. He, L.; Zhu, W.; Chen, Q.; Yuan, Y.; Wang, Y.; Wang, J.; Wu, X. Ovarian cancer cell-secreted exosomal miR-205 promotes metastasis by inducing angiogenesis. Theranostics 2019, 9, 8206-8220. [CrossRef]

48. Sun, S.L.; Shu, Y.G.; Tao, M.Y. miR-503 Inhibits Proliferation, Migration, And Angiogenesis of Glioma by Acting on VEGFA through Targeting LRIG2. Cancer Manag. Res. 2019, 11, 10599-10608. [CrossRef]

49. Mu, H.Q.; He, Y.H.; Wang, S.B.; Yang, S.; Wang, Y.J.; Nan, C.J.; Bao, Y.F.; Xie, Q.P.; Chen, Y.H. MiR-130b/TNF- $\alpha /$ NF-kB/VEGFA loop inhibits prostate cancer angiogenesis. Clin. Transl. Oncol. 2020, 22, 111-121. [CrossRef]

50. Yang, F.; Shao, C.; Wei, K.; Jing, X.; Qin, Z.; Shi, Y.; Shu, Y.; Shen, H. miR-942 promotes tumor migration, invasion, and angiogenesis by regulating EMT via BARX2 in non-small-cell lung cancer. J. Cell Physiol. 2019, 234, 23596-23607. [CrossRef]

51. Pourdavoud, P.; Pakzad, B.; Mosallaei, M.; Saadatian, Z.; Esmaeilzadeh, E.; Alimolaie, A.; Shaygannejad, A. MiR-196: Emerging of a new potential therapeutic target and biomarker in colorectal cancer. Mol. Biol. Rep. 2020, 47, 9913-9920. [CrossRef] [PubMed]

52. Dong, Y.; Zhang, N.; Zhao, S.; Chen, X.; Li, F.; Tao, X. miR-221-3p and miR-15b-5p promote cell proliferation and invasion by targeting Axin2 in liver cancer. Oncol. Lett. 2019, 18, 6491-6500. [CrossRef]

53. Wei, J.; Yang, L.; Wu, Y.N.; Xu, J. Serum miR-1290 and miR-1246 as Potential Diagnostic Biomarkers of Human Pancreatic Cancer. J. Cancer 2020, 11, 1325-1333. [CrossRef]

54. Xu, X.; Jiang, X.; Chen, L.; Zhao, Y.; Huang, Z.; Zhou, H.; Shi, M. MiR-181a Promotes Apoptosis and Reduces Cisplatin Resistance by Inhibiting Osteopontin in Cervical Cancer Cells. Cancer Biother. Radiopharm. 2019, 34, 559-565. [CrossRef]

55. Tang, H.; Song, C.; Ye, F.; Gao, G.; Ou, X.; Zhang, L.; Xie, X.; Xie, X. miR-200c suppresses stemness and increases cellular sensitivity to trastuzumab in HER2+ breast cancer. J. Cell Mol. Med. 2019, 23, 8114-8127. [CrossRef]

56. Yan, S.; Wang, H.; Chen, X.; Liang, C.; Shang, W.; Wang, L.; Li, J.; Xu, D. MiR-182-5p inhibits colon cancer tumorigenesis, angiogenesis, and lymphangiogenesis by directly downregulating VEGF-C. Cancer Lett. 2020, 488, 18-26. [CrossRef]

57. Dai, W.; Zhou, J.; Wang, H.; Zhang, M.; Yang, X.; Song, W. miR-424-5p promotes the proliferation and metastasis of colorectal cancer by directly targeting SCN4B. Pathol. Res. Pract. 2020, 216, 152731. [CrossRef] 
58. Zhou, Y.; He, A.; Zhang, L.; Yi, G. MiR-744 mediates the Oxaliplatin chemoresistance in colorectal cancer through inhibiting BIN1. Neoplasma 2020, 67, 296-303. [CrossRef]

59. Lv, L.; Li, Q.; Chen, S.; Zhang, X.; Tao, X.; Tang, X.; Wang, S.; Che, G.; Yu, Y.; He, L. miR-133b suppresses colorectal cancer cell stemness and chemoresistance by targeting methyltransferase DOT1L. Exp. Cell Res. 2019, 385, 111597. [CrossRef]

60. Yang, L.W.; Wu, X.J.; Liang, Y.; Ye, G.Q.; Che, Y.C.; Wu, X.Z.; Zhu, X.J.; Fan, H.L.; Fan, X.P.; Xu, J.F. miR-155 increases stemness and decitabine resistance in triple-negative breast cancer cells by inhibiting TSPAN5. Mol. Carcinog 2020, 59, 447-461. [CrossRef] [PubMed]

61. Tang, X.; Ding, Y.; Wang, X.; Wang, X.; Zhao, L.; Bi, H. miR-650 promotes non-small cell lung cancer cell proliferation and invasion by targeting ING4 through Wnt-1/ $\beta$-catenin pathway. Oncol. Lett. 2019, 18, 4621-4628. [CrossRef] [PubMed]

62. Peng, W.; Dong, N.; Wu, S.; Gui, D.; Ye, Z.; Wu, H.; Zhong, X. miR-4500 suppresses cell proliferation and migration in bladder cancer via inhibition of STAT3/CCR7 pathway. J. Cell Biochem. 2019. [CrossRef]

63. Wu, G.; Zheng, H.; Xu, J.; Guo, Y.; Zheng, G.; Ma, C.; Hao, S.; Liu, X.; Chen, H.; Wei, S.; et al. miR-429 suppresses cell growth and induces apoptosis of human thyroid cancer cell by targeting ZEB1. Artif. Cells Nanomed. Biotechnol. 2019, 47, 548-554. [CrossRef]

64. Zhang, P.F.; Pei, X.; Li, K.S.; Jin, L.N.; Wang, F.; Wu, J.; Zhang, X.M. Circular RNA circFGFR1 promotes progression and anti-PD-1 resistance by sponging miR-381-3p in non-small cell lung cancer cells. Mol. Cancer 2019, 18, 179. [CrossRef] [PubMed]

65. Hou, Z.H.; Xu, X.W.; Fu, X.Y.; Zhou, L.D.; Liu, S.P.; Tan, D.M. Long non-coding RNA MALAT1 promotes angiogenesis and immunosuppressive properties of HCC cells by sponging miR-140. Am. J. Physiol. Cell Physiol. 2020, 318, 649-663. [CrossRef] [PubMed]

66. Ho, J.; Cruise, E.S.; Dowling, R.J.; Stambolic, V. PTEN nuclear functions. Cold Spring Harb. Perspect. Med. 2020, 10. [CrossRef]

67. Ashrafizadeh, M.; Najafi, M.; Ang, H.L.; Moghadam, E.R.; Mahabady, M.K.; Zabolian, A.; Jafaripour, L.; Bejandi, A.K.; Hushmandi, K.; Saleki, H.; et al. PTEN, a Barrier for Proliferation and Metastasis of Gastric Cancer Cells: From Molecular Pathways to Targeting and Regulation. Biomedicines 2020, 8, 264. [CrossRef] [PubMed]

68. Braglia, L.; Zavatti, M.; Vinceti, M.; Martelli, A.M.; Marmiroli, S. Deregulated PTEN/PI3K/AKT/mTOR signaling in prostate cancer: Still a potential druggable target? Biochim. Biophys. Acta BBA Mol. Cell Res. 2020, 118731. [CrossRef] [PubMed]

69. Siveen, K.S.; Ahn, K.S.; Ong, T.H.; Shanmugam, M.K.; Li, F.; Yap, W.N.; Kumar, A.P.; Fong, C.W.; Tergaonkar, V.; Hui, K.M.; et al. Y-tocotrienol inhibits angiogenesis-dependent growth of human hepatocellular carcinoma through abrogation of AKT/mTOR pathway in an orthotopic mouse model. Oncotarget 2014, 5, 1897-1911. [CrossRef] [PubMed]

70. Ong, P.S.; Wang, L.Z.; Dai, X.; Tseng, S.H.; Loo, S.J.; Sethi, G. Judicious Toggling of mTOR Activity to Combat Insulin Resistance and Cancer: Current Evidence and Perspectives. Front. Pharmacol. 2016, 7, 395. [CrossRef]

71. Singh, S.S.; Yap, W.N.; Arfuso, F.; Kar, S.; Wang, C.; Cai, W.; Dharmarajan, A.M.; Sethi, G.; Kumar, A.P. Targeting the PI3K/Akt signaling pathway in gastric carcinoma: A reality for personalized medicine? World J. Gastroenterol. 2015, 21, 12261-12273. [CrossRef]

72. Mohan, C.D.; Srinivasa, V.; Rangappa, S.; Mervin, L.; Mohan, S.; Paricharak, S.; Baday, S.; Li, F.; Shanmugam, M.K.; Chinnathambi, A.; et al. Trisubstituted-Imidazoles Induce Apoptosis in Human Breast Cancer Cells by Targeting the Oncogenic PI3K/Akt/mTOR Signaling Pathway. PLoS ONE 2016, 11, e0153155. [CrossRef]

73. Stokoe, D.; Stephens, L.R.; Copeland, T.; Gaffney, P.R.; Reese, C.B.; Painter, G.F.; Holmes, A.B.; McCormick, F.; Hawkins, P.T. Dual role of phosphatidylinositol-3, 4, 5-trisphosphate in the activation of protein kinase B. Science 1997, 277, 567-570. [CrossRef]

74. Calleja, V.; Laguerre, M.; Parker, P.J.; Larijani, B. Role of a novel PH-kinase domain interface in PKB/Akt regulation: Structural mechanism for allosteric inhibition. PLoS Biol. 2009, 7, e1000017. [CrossRef]

75. Lee, J.H.; Kim, C.; Um, J.Y.; Sethi, G.; Ahn, K.S. Casticin-Induced Inhibition of Cell Growth and Survival Are Mediated through the Dual Modulation of Akt/mTOR Signaling Cascade. Cancers 2019, 11, 254. [CrossRef]

76. Si, X.; Xu, F.; Xu, F.; Wei, M.; Ge, Y.; Chenge, S. CADM1 inhibits ovarian cancer cell proliferation and migration by potentially regulating the PI3K/Akt/mTOR pathway. Biomed. Pharmacother. 2020, 123, 109717. [CrossRef] [PubMed]

77. Won, Y.S.; Seo, K.I. Lupiwighteone induces caspase-dependent and -independent apoptosis on human breast cancer cells via inhibiting PI3K/Akt/mTOR pathway. Food Chem. Toxicol 2020, 135, 110863. [CrossRef]

78. Bu, T.; Wang, C.; Jin, H.; Meng, Q.; Huo, X.; Sun, H.; Sun, P.; Wu, J.; Ma, X.; Liu, Z.; et al. Organic anion transporters and PI3K-AKT-mTOR pathway mediate the synergistic anticancer effect of pemetrexed and rhein. J. Cell Physiol. 2020, 235, 3309-3319. [CrossRef] [PubMed]

79. Perez-Juarez, C.E.; Arechavaleta-Velasco, F.; Zeferino-Toquero, M.; Alvarez-Arellano, L.; Estrada-Moscoso, I.; Diaz-Cueto, L. Inhibition of PI3K/AKT/mTOR and MAPK signaling pathways decreases progranulin expression in ovarian clear cell carcinoma (OCCC) cell line: A potential biomarker for therapy response to signaling pathway inhibitors. Med. Oncol. 2019, 37, 4. [CrossRef]

80. Jiang, C.; Zeng, X.; Shan, R.; Wen, W.; Li, J.; Tan, J.; Li, L.; Wan, R. The Emerging Picture of the Roles of CircRNA-CDR1as in Cancer. Front Cell Dev Biol 2020, 8, 590478. [CrossRef]

81. Lee, J.H.; Chinnathambi, A.; Alharbi, S.A.; Shair, O.H.; Sethi, G.; Ahn, K.S. Farnesol abrogates epithelial to mesenchymal transition process through regulating Akt/mTOR pathway. Pharmacol. Res. 2019, 150, 104504. [CrossRef] [PubMed]

82. Vidotto, T.; Melo, C.M.; Castelli, E.; Koti, M.; dos Reis, R.B.; Squire, J.A. Emerging role of PTEN loss in evasion of the immune response to tumours. Br. J. Cancer 2020, 1-12. [CrossRef] [PubMed]

83. Bassi, C.; Ho, J.; Srikumar, T.; Dowling, R.; Gorrini, C.; Miller, S.; Mak, T.; Neel, B.; Raught, B.; Stambolic, V. Nuclear PTEN controls DNA repair and sensitivity to genotoxic stress. Science 2013, 341, 395-399. [CrossRef]

84. Shen, W.H.; Balajee, A.S.; Wang, J.; Wu, H.; Eng, C.; Pandolfi, P.P.; Yin, Y. Essential role for nuclear PTEN in maintaining chromosomal integrity. Cell 2007, 128, 157-170. [CrossRef] 
85. Baek, S.H.; Lee, J.H.; Kim, C.; Ko, J.H.; Ryu, S.H.; Lee, S.G.; Yang, W.M.; Um, J.Y.; Chinnathambi, A.; Alharbi, S.A.; et al. Ginkgolic Acid C 17:1, Derived from Ginkgo biloba Leaves, Suppresses Constitutive and Inducible STAT3 Activation through Induction of PTEN and SHP-1 Tyrosine Phosphatase. Molecules 2017, 22, 276. [CrossRef] [PubMed]

86. Costa, C.; Wang, Y.; Ly, A.; Hosono, Y.; Murchie, E.; Walmsley, C.S.; Huynh, T.; Healy, C.; Peterson, R.; Yanase, S.; et al. PTEN Loss Mediates Clinical Cross-Resistance to CDK4/6 and PI3K $\alpha$ Inhibitors in Breast Cancer. Cancer Discov. 2020, 10, 72-85. [CrossRef] [PubMed]

87. Chen, H.; Wang, X.; Chen, Y.; Han, J.; Kong, D.; Zhu, M.; Fu, X.; Wu, Y. Pten loss in Lgr5(+) hair follicle stem cells promotes SCC development. Theranostics 2019, 9, 8321-8331. [CrossRef] [PubMed]

88. Qian, X.; Li, X.; Shi, Z.; Xia, Y.; Cai, Q.; Xu, D.; Tan, L.; Du, L.; Zheng, Y.; Zhao, D.; et al. PTEN Suppresses Glycolysis by Dephosphorylating and Inhibiting Autophosphorylated PGK1. Mol. Cell 2019, 76, 516-527. [CrossRef]

89. Liu, Y.; Lin, F.; Chen, Y.; Wang, R.; Liu, J.; Jin, Y.; An, R. Cryptotanshinone Inhibites Bladder Cancer Cell Proliferation and Promotes Apoptosis via the PTEN/PI3K/AKT Pathway. J. Cancer 2020, 11, 488-499. [CrossRef] [PubMed]

90. Liang, Y.; Zhu, D.; Zhu, L.; Hou, Y.; Hou, L.; Huang, X.; Li, L.; Wang, Y.; Li, L.; Zou, H.; et al. Dichloroacetate Overcomes Oxaliplatin Chemoresistance in Colorectal Cancer through the miR-543/PTEN/Akt/mTOR Pathway. J. Cancer 2019, 10, 6037-6047. [CrossRef]

91. Lee, J.H.; Mohan, C.D.; Deivasigamani, A.; Jung, Y.Y.; Rangappa, S.; Basappa, S.; Chinnathambi, A.; Alahmadi, T.A.; Alharbi, S.A.; Garg, M.; et al. Brusatol suppresses STAT3-driven metastasis by downregulating epithelial-mesenchymal transition in hepatocellular carcinoma. J. Adv. Res. 2020. [CrossRef]

92. Qi, Y.; Liu, J.; Chao, J.; Scheuerman, M.P.; Rahimi, S.A.; Lee, L.Y.; Li, S. PTEN suppresses epithelial-mesenchymal transition and cancer stem cell activity by downregulating Abi1. Sci. Rep. 2020, 10, 12685. [CrossRef]

93. Fang, S.; Zhang, D.; Weng, W.; Lv, X.; Zheng, L.; Chen, M.; Fan, X.; Mao, J.; Mao, C.; Ye, Y.; et al. CPSF7 regulates liver cancer growth and metastasis by facilitating WWP2-FL and targeting the WWP2/PTEN/AKT signaling pathway. Biochim. Biophys. Acta. Mol. Cell Res. 2020, 1867, 118624. [CrossRef]

94. Ma, L.; Yao, N.; Chen, P.; Zhuang, Z. TRIM27 promotes the development of esophagus cancer via regulating PTEN/AKT signaling pathway. Cancer Cell Int. 2019, 19, 283. [CrossRef] [PubMed]

95. Fan, J.P.; Qian, J.; Zhao, Y.J. The loss of PTEN expression and microsatellite stability (MSS) were predictors of unfavorable prognosis in gastric cancer (GC). Neoplasma 2020. [CrossRef] [PubMed]

96. Luo, S.; Chen, J.; Mo, X. The association of PTEN hypermethylation and breast cancer: A meta-analysis. Onco. Targets Ther. 2016, 9, 5643-5650. [CrossRef] [PubMed]

97. Yari, K.; Payandeh, M.; Rahimi, Z. Association of the hypermethylation status of PTEN tumor suppressor gene with the risk of breast cancer among Kurdish population from Western Iran. Tumour Biol. 2016, 37, 8145-8152. [CrossRef]

98. Buckingham, L.; Penfield Faber, L.; Kim, A.; Liptay, M.; Barger, C.; Basu, S.; Fidler, M.; Walters, K.; Bonomi, P.; Coon, J. PTEN, RASSF1 and DAPK site-specific hypermethylation and outcome in surgically treated stage I and II nonsmall cell lung cancer patients. Int. J. Cancer 2010, 126, 1630-1639. [CrossRef]

99. Yu, D.; Wang, X.Y.; Jin, Z.L. Linc00702 inhibits cell growth and metastasis through regulating PTEN in colorectal cancer. Eur. Rev. Med. Pharmacol. Sci. 2020, 24, 3624-3632. [CrossRef]

100. Yan, J.; Huang, X.; Zhang, X.; Chen, Z.; Ye, C.; Xiang, W.; Huang, Z. LncRNA LINC00470 promotes the degradation of PTEN mRNA to facilitate malignant behavior in gastric cancer cells. Biochem. Biophys. Res. Commun. 2020, 521, 887-893. [CrossRef]

101. Dai, X.; Guo, X.; Liu, J.; Cheng, A.; Peng, X.; Zha, L.; Wang, Z. Circular RNA circGRAMD1B inhibits gastric cancer progression by sponging miR-130a-3p and regulating PTEN and p21 expression. Aging 2019, 11, 9689-9708. [CrossRef]

102. Duan, X.M.; Liu, X.N.; Li, Y.X.; Cao, Y.Q.; Silayiding, A.; Zhang, R.K.; Wang, J.P. MicroRNA-498 promotes proliferation, migration, and invasion of prostate cancer cells and decreases radiation sensitivity by targeting PTEN. Kaohsiung J. Med. Sci. 2019, 35, 659-671. [CrossRef]

103. Shi, Y.P.; Liu, G.L.; Li, S.; Liu, X.L. miR-17-5p knockdown inhibits proliferation, autophagy and promotes apoptosis in thyroid cancer via targeting PTEN. Neoplasma 2020, 67, 249-258. [CrossRef]

104. Li, N.; Miao, Y.; Shan, Y.; Liu, B.; Li, Y.; Zhao, L.; Jia, L. MiR-106b and miR-93 regulate cell progression by suppression of PTEN via PI3K/Akt pathway in breast cancer. Cell Death Dis. 2017, 8, 2796. [CrossRef] [PubMed]

105. Zhao, Y.; Li, C.; Wang, M.; Su, L.; Qu, Y.; Li, J.; Yu, B.; Yan, M.; Yu, Y.; Liu, B.; et al. Decrease of miR-202-3p expression, a novel tumor suppressor, in gastric cancer. PLoS ONE 2013, 8, e69756. [CrossRef]

106. Li, Y.G.; He, J.H.; Yu, L.; Hang, Z.P.; Li, W.; Shun, W.H.; Huang, G.X. microRNA-202 suppresses MYCN expression under the control of E2F1 in the neuroblastoma cell line LAN-5. Mol. Med. Rep. 2014, 9, 541-546. [CrossRef] [PubMed]

107. Liu, T.; Guo, J.; Zhang, X. MiR-202-5p/PTEN mediates doxorubicin-resistance of breast cancer cells via PI3K/Akt signaling pathway. Cancer Biol. Ther. 2019, 20, 989-998. [CrossRef]

108. Kia, V.; Sharif Beigli, M.; Hosseini, V.; Koochaki, A.; Paryan, M.; Mohammadi-Yeganeh, S. Is miR-144 an effective inhibitor of PTEN mRNA: A controversy in breast cancer. In Vitro Cell Dev. Biol. Anim. 2018, 54, 621-628. [CrossRef] [PubMed]

109. Zhang, W.L.; Zhang, J.H. miR-181c promotes proliferation via suppressing PTEN expression in inflammatory breast cancer. Int. J. Oncol. 2015, 46, 2011-2020. [CrossRef]

110. Xin, Y.; Wang, X.; Meng, K.; Ni, C.; Lv, Z.; Guan, D. Identification of exosomal miR-455-5p and miR-1255a as therapeutic targets for breast cancer. Biosci. Rep. 2020, 40. [CrossRef] 
111. Li, D.; Wang, J.; Ma, L.J.; Yang, H.B.; Jing, J.F.; Jia, M.M.; Zhang, X.J.; Guo, F.; Gao, J.N. Identification of serum exosomal miR-148a as a novel prognostic biomarker for breast cancer. Eur. Rev. Med. Pharmacol Sci. 2020, 24, 7303-7309. [CrossRef] [PubMed]

112. Kia, V.; Paryan, M.; Mortazavi, Y.; Biglari, A.; Mohammadi-Yeganeh, S. Evaluation of exosomal miR-9 and miR-155 targeting PTEN and DUSP14 in highly metastatic breast cancer and their effect on low metastatic cells. J. Cell Biochem. 2019, 120, 5666-5676. [CrossRef] [PubMed]

113. Schwarzenbach, H.; Milde-Langosch, K.; Steinbach, B.; Müller, V.; Pantel, K. Diagnostic potential of PTEN-targeting miR-214 in the blood of breast cancer patients. Breast Cancer Res. Treat. 2012, 134, 933-941. [CrossRef]

114. Walter, B.A.; Gómez-Macias, G.; Valera, V.A.; Sobel, M.; Merino, M.J. miR-21 Expression in Pregnancy-Associated Breast Cancer: A Possible Marker of Poor Prognosis. J. Cancer 2011, 2, 67-75. [CrossRef]

115. Xiao, S.; Zhu, H.; Luo, J.; Wu, Z.; Xie, M. miR-425-5p is associated with poor prognosis in patients with breast cancer and promotes cancer cell progression by targeting PTEN. Oncol. Rep. 2019, 42, 2550-2560. [CrossRef]

116. Clarke, M.F.; Fuller, M. Stem cells and cancer: Two faces of eve. Cell 2006, 124, 1111-1115. [CrossRef]

117. Ma, Z.; Wang, Y.Y.; Xin, H.W.; Wang, L.; Arfuso, F.; Dharmarajan, A.; Kumar, A.P.; Wang, H.; Tang, F.R.; Warrier, S.; et al. The expanding roles of long non-coding RNAs in the regulation of cancer stem cells. Int. J. Biochem. Cell Biol. 2019, 108, 17-20. [CrossRef]

118. Ginestier, C.; Hur, M.H.; Charafe-Jauffret, E.; Monville, F.; Dutcher, J.; Brown, M.; Jacquemier, J.; Viens, P.; Kleer, C.G.; Liu, S. ALDH1 is a marker of normal and malignant human mammary stem cells and a predictor of poor clinical outcome. Cell Stem Cell 2007, 1, 555-567. [CrossRef] [PubMed]

119. Charafe-Jauffret, E.; Ginestier, C.; Iovino, F.; Tarpin, C.; Diebel, M.; Esterni, B.; Houvenaeghel, G.; Extra, J.-M.; Bertucci, F.; Jacquemier, J. Aldehyde dehydrogenase 1-Positive cancer stem cells mediate metastasis and poor clinical outcome in inflammatory breast cancer. Clinl. Cancer Res. 2010, 16, 45-55. [CrossRef] [PubMed]

120. Ginestier, C.; Liu, S.; Diebel, M.E.; Korkaya, H.; Luo, M.; Brown, M.; Wicinski, J.; Cabaud, O.; Charafe-Jauffret, E.; Birnbaum, D. CXCR1 blockade selectively targets human breast cancer stem cells in vitro and in xenografts. J. Clin. Investig. 2010, 120, 485-497. [CrossRef]

121. Li, B.; Lu, Y.; Wang, H.; Han, X.; Mao, J.; Li, J.; Yu, L.; Wang, B.; Fan, S.; Yu, X.; et al. miR-221/222 enhance the tumorigenicity of human breast cancer stem cells via modulation of PTEN/Akt pathway. Biomed. Pharmacother. 2016, 79, 93-101. [CrossRef] [PubMed]

122. Wei, H.; Cui, R.; Bahr, J.; Zanesi, N.; Luo, Z.; Meng, W.; Liang, G.; Croce, C.M. miR-130a Deregulates PTEN and Stimulates Tumor Growth. Cancer Res. 2017, 77, 6168-6178. [CrossRef]

123. Xie, Y.; Zhao, J.; Liang, Y.; Chen, M.; Luo, Y.; Cui, X.; Jiang, B.; Peng, L.; Wang, X. MicroRNA-10b controls the metastasis and proliferation of colorectal cancer cells by regulating Krüppel-like factor 4. Artif. Cells Nanomed. Biotechnol. 2019, 47, 1722-1729. [CrossRef]

124. Zhang, Q.; Zhang, J.; Fu, Z.; Dong, L.; Tang, Y.; Xu, C.; Wang, H.; Zhang, T.; Wu, Y.; Dong, C.; et al. Hypoxia-induced microRNA-10b-3p promotes esophageal squamous cell carcinoma growth and metastasis by targeting TSGA10. Aging 2019, 11, 10374-10384. [CrossRef]

125. Xu, C.; Qi, X. MiR-10b inhibits migration and invasion of pancreatic ductal adenocarcinoma via regulating E2F7. J. Clin. Lab. Anal. 2020, e23442. [CrossRef]

126. Bahena-Ocampo, I.; Espinosa, M.; Ceballos-Cancino, G.; Lizarraga, F.; Campos-Arroyo, D.; Schwarz, A.; Maldonado, V.; MelendezZajgla, J.; Garcia-Lopez, P. miR-10b expression in breast cancer stem cells supports self-renewal through negative PTEN regulation and sustained AKT activation. EMBO Rep. 2016, 17, 648-658. [CrossRef] [PubMed]

127. Zhao, Y.S.; Yang, W.C.; Xin, H.W.; Han, J.X.; Ma, S.G. MiR-182-5p Knockdown Targeting PTEN Inhibits Cell Proliferation and Invasion of Breast Cancer Cells. Yonsei Med. J. 2019, 60, 148-157. [CrossRef] [PubMed]

128. Wang, C.; Bian, Z.; Wei, D.; Zhang, J.G. miR-29b regulates migration of human breast cancer cells. Mol. Cell Biochem. 2011, 352, 197-207. [CrossRef]

129. Brody, J.G.; Moysich, K.B.; Humblet, O.; Attfield, K.R.; Beehler, G.P.; Rudel, R.A. Environmental pollutants and breast cancer: Epidemiologic studies. Cancer Interdiscip. Int. J. Am. Cancer Soc. 2007, 109, 2667-2711. [CrossRef] [PubMed]

130. Brody, J.G.; Rudel, R.A.; Michels, K.B.; Moysich, K.B.; Bernstein, L.; Attfield, K.R.; Gray, S. Environmental pollutants, diet, physical activity, body size, and breast cancer: Where do we stand in research to identify opportunities for prevention? Cancer Interdiscip. Int. J. Am. Cancer Soc. 2007, 109, 2627-2634. [CrossRef]

131. Wu, J.; Jiang, Y.; Cao, W.; Li, X.; Xie, C.; Geng, S.; Zhu, M.; Liang, Z.; Zhu, J.; Zhu, W.; et al. miR-19 targeting of PTEN mediates butyl benzyl phthalate-induced proliferation in both ER(+) and ER(-) breast cancer cells. Toxicol. Lett. 2018, 295, 124-133. [CrossRef] [PubMed]

132. Liu, H.; Song, Y.; Qiu, H.; Liu, Y.; Luo, K.; Yi, Y.; Jiang, G.; Lu, M.; Zhang, Z.; Yin, J.; et al. Downregulation of FOXO3a by DNMT1 promotes breast cancer stem cell properties and tumorigenesis. Cell Death Differ. 2020, 27, 966-983. [CrossRef] [PubMed]

133. Pellegrino, M.; Rizza, P.; Donà, A.; Nigro, A.; Ricci, E.; Fiorillo, M.; Perrotta, I.; Lanzino, M.; Giordano, C.; Bonofiglio, D.; et al. FoxO3a as a Positive Prognostic Marker and a Therapeutic Target in Tamoxifen-Resistant Breast Cancer. Cancers 2019, 11, 1858. [CrossRef]

134. Liang, C.; Pang, L.; Ke, Y.; Ji, W.; Xiong, J.; Ding, R.; Ding, Y. LncRNA GAS6-AS2 facilitates tumor growth and metastasis of hepatocellular carcinoma by activating the PI3K/AKT/FoxO3a signaling pathway. Int. J. Clin. Exp. Pathol. 2019, 12, $4011-4023$.

135. Yu, Y.; Yang, L.; Han, S.; Wu, Y.; Liu, L.; Chang, Y.; Wang, X.; Chai, J. MIR-190B Alleviates Cell Autophagy and Burn-Induced Skeletal Muscle Wasting via Modulating PHLPP1/Akt/FoxO3A Signaling Pathway. Shock 2019, 52, 513-521. [CrossRef]

136. Ma, Z.; Yu, R.; Zhu, Q.; Sun, L.; Jian, L.; Wang, X.; Zhao, J.; Li, C.; Liu, X. CXCL16/CXCR6 axis promotes bleomycin-induced fibrotic process in MRC-5 cells via the PI3K/AKT/FOXO3a pathway. Int. Immunopharmacol. 2020, 81, 106035. [CrossRef] 
137. Liu, X.; Feng, J.; Tang, L.; Liao, L.; Xu, Q.; Zhu, S. The regulation and function of miR-21-FOXO3a-miR-34b/c signaling in breast cancer. Int. J. Mol. Sci. 2015, 16, 3148-3162. [CrossRef]

138. Yao, X.; Tu, Y.; Xu, Y.; Guo, Y.; Yao, F.; Zhang, X. Endoplasmic reticulum stress-induced exosomal miR-27a-3p promotes immune escape in breast cancer via regulating PD-L1 expression in macrophages. J. Cell. Mol. Med. 2020, 24, 9560-9573. [CrossRef] [PubMed]

139. Li, W.; Li, H.; Zhang, L.; Hu, M.; Li, F.; Deng, J.; An, M.; Wu, S.; Ma, R.; Lu, J.; et al. Long non-coding RNA LINC00672 contributes to $\mathrm{p} 53$ protein-mediated gene suppression and promotes endometrial cancer chemosensitivity. J. Biol. Chem. 2017, 292, 5801-5813. [CrossRef]

140. Li, B.; Lu, Y.; Yu, L.; Han, X.; Wang, H.; Mao, J.; Shen, J.; Wang, B.; Tang, J.; Li, C.; et al. miR-221/222 promote cancer stem-like cell properties and tumor growth of breast cancer via targeting PTEN and sustained Akt/NF- $\mathrm{B} / \mathrm{COX}-2$ activation. Chem. Biol. Interact. 2017, 277, 33-42. [CrossRef]

141. Han, M.; Liu, M.; Wang, Y.; Chen, X.; Xu, J.; Sun, Y.; Zhao, L.; Qu, H.; Fan, Y.; Wu, C. Antagonism of miR-21 reverses epithelialmesenchymal transition and cancer stem cell phenotype through AKT/ERK1/2 inactivation by targeting PTEN. PLoS ONE 2012, 7, e39520. [CrossRef]

142. Lee, S.; Lee, H.; Bae, H.; Choi, E.H.; Kim, S.J. Epigenetic silencing of miR-19a-3p by cold atmospheric plasma contributes to proliferation inhibition of the MCF-7 breast cancer cell. Sci. Rep. 2016, 6, 30005. [CrossRef] [PubMed]

143. Wang, J.; Chen, H.; Liao, Y.; Chen, N.; Liu, T.; Zhang, H.; Zhang, H. Expression and clinical evidence of miR-494 and PTEN in non-small cell lung cancer. Tumour Biol. 2015, 36, 6965-6972. [CrossRef]

144. Xie, X.; Liu, H.T.; Mei, J.; Ding, F.B.; Xiao, H.B.; Hu, F.Q.; Hu, R.; Wang, M.S. miR-106a promotes growth and metastasis of non-small cell lung cancer by targeting PTEN. Int. J. Clin. Exp. Pathol. 2015, 8, 3827-3834.

145. Ren, W.; Hou, J.; Yang, C.; Wang, H.; Wu, S.; Wu, Y.; Zhao, X.; Lu, C. Extracellular vesicles secreted by hypoxia pre-challenged mesenchymal stem cells promote non-small cell lung cancer cell growth and mobility as well as macrophage M2 polarization via miR-21-5p delivery. J. Exp. Clin. Cancer Res. 2019, 38, 62. [CrossRef]

146. Gao, Z.J.; Yuan, W.D.; Yuan, J.Q.; Yuan, K.; Wang, Y. miR-486-5p functions as an oncogene by targeting PTEN in non-small cell lung cancer. Pathol. Res. Pract. 2018, 214, 700-705. [CrossRef]

147. Yang, W.; Bai, J.; Liu, D.; Wang, S.; Zhao, N.; Che, R.; Zhang, H. MiR-93-5p up-regulation is involved in non-small cell lung cancer cells proliferation and migration and poor prognosis. Gene 2018, 647, 13-20. [CrossRef] [PubMed]

148. Xue, X.; Liu, Y.; Wang, Y.; Meng, M.; Wang, K.; Zang, X.; Zhao, S.; Sun, X.; Cui, L.; Pan, L.; et al. MiR-21 and MiR-155 promote non-small cell lung cancer progression by downregulating SOCS1, SOCS6, and PTEN. Oncotarget 2016, 7, 84508-84519. [CrossRef] [PubMed]

149. Hou, Q.; Jiang, Z.; Li, Y.; Wu, H.; Yu, J.; Jiang, M. FAM60A promotes cisplatin resistance in lung cancer cells by activating SKP2 expression. Anti-Cancer Drugs 2020, 31, 776-784. [CrossRef]

150. Bu, W.; Luo, T. miR-1297 Promotes Cell Proliferation of Non-Small Cell Lung Cancer Cells: Involving in PTEN/Akt/Skp2 Signaling Pathway. DNA Cell Biol. 2017, 36, 976-982. [CrossRef]

151. Ahn, K.J.; Kim, J.; Yun, M.; Park, J.H.; Lee, J.D. Enzymatic properties of the N-and C-terminal halves of human hexokinase II. BMB Rep. 2009. [CrossRef]

152. Popescu, N.C.; Cheng, S.-y. Chromosomal localization of the gene for a human cytosolic thyroid hormone binding protein homologous to the subunit of pyruvate kinase, subtype M 2. Somatic Cell Mol. Genet. 1990, 16, 593-598. [CrossRef] [PubMed]

153. Zhang, K.; Zhang, M.; Jiang, H.; Liu, F.; Liu, H.; Li, Y. Down-regulation of miR-214 inhibits proliferation and glycolysis in non-small-cell lung cancer cells via down-regulating the expression of hexokinase 2 and pyruvate kinase isozyme M2. Biomed. Pharmacother. 2018, 105, 545-552. [CrossRef]

154. Zhu, D.Y.; Li, X.N.; Qi, Y.; Liu, D.L.; Yang, Y.; Zhao, J.; Zhang, C.Y.; Wu, K.; Zhao, S. MiR-454 promotes the progression of human non-small cell lung cancer and directly targets PTEN. Biomed. Pharmacother 2016, 81, 79-85. [CrossRef]

155. Aquila, S.; Santoro, M.; Caputo, A.; Panno, M.L.; Pezzi, V.; De Amicis, F. The Tumor Suppressor PTEN as Molecular Switch Node Regulating Cell Metabolism and Autophagy: Implications in Immune System and Tumor Microenvironment. Cells 2020, 9, 1725. [CrossRef] [PubMed]

156. Wu, W.; Jing, D.; Meng, Z.; Hu, B.; Zhong, B.; Deng, X.; Jin, X.; Shao, Z. FGD1 promotes tumor progression and regulates tumor immune response in osteosarcoma via inhibiting PTEN activity. Theranostics 2020, 10, 2859-2871. [CrossRef]

157. Wan, J.; Ling, X.; Peng, B.; Ding, G. miR-142-5p regulates CD4+ T cells in human non-small cell lung cancer through PD-L1 expression via the PTEN pathway. Oncol. Rep. 2018, 40, 272-282. [CrossRef]

158. Hu, P.; Zhou, L.; Wang, C.; Cao, G.; Chang, Y. MiR-181a reduces radiosensitivity of non-small cell lung cancer via inhibiting PTEN. Panminerva Med. 2020. [CrossRef]

159. Zhang, J.; Zhang, C.; Hu, L.; He, Y.; Shi, Z.; Tang, S.; Chen, Y. Abnormal Expression of miR-21 and miR-95 in Cancer Stem-Like Cells is Associated with Radioresistance of Lung Cancer. Cancer Investig. 2015, 33, 165-171. [CrossRef]

160. Zheng, Y.; Liu, L.; Chen, C.; Ming, P.; Huang, Q.; Li, C.; Cao, D.; Xu, X.; Ge, W. The extracellular vesicles secreted by lung cancer cells in radiation therapy promote endothelial cell angiogenesis by transferring miR-23a. PeerJ. 2017, 5, e3627. [CrossRef] [PubMed]

161. Xu, Q.; Ma, H.; Chang, H.; Feng, Z.; Zhang, C.; Yang, X. The interaction of interleukin-8 and PTEN inactivation promotes the malignant progression of head and neck squamous cell carcinoma via the STAT3 pathway. Cell Death Dis. 2020, 11, 405. [CrossRef] 
162. Yuan, B.; Sun, R.; Du, Y.; Jia, Z.; Yao, W.; Yang, J. STAT3-Induced Upregulation of lncRNA CASC9 Promotes the Progression of Bladder Cancer by Interacting with EZH2 and Affecting the Expression of PTEN. Onco. Targets Ther. 2020, 13, 9147-9157. [CrossRef] [PubMed]

163. Parashar, D.; Geethadevi, A.; Aure, M.R.; Mishra, J.; George, J.; Chen, C.; Mishra, M.K.; Tahiri, A.; Zhao, W.; Nair, B.; et al. miRNA551b-3p Activates an Oncostatin Signaling Module for the Progression of Triple-Negative Breast Cancer. Cell Rep. 2019, 29, 4389-4406. [CrossRef]

164. Zhang, W.; Bai, W.; Zhang, W. MiR-21 suppresses the anticancer activities of curcumin by targeting PTEN gene in human non-small cell lung cancer A549 cells. Clin. Transl. Oncol. 2014, 16, 708-713. [CrossRef]

165. Guerriero, I.; D’Angelo, D.; Pallante, P.; Santos, M.; Scrima, M.; Malanga, D.; De Marco, C.; Ravo, M.; Weisz, A.; Laudanna, C.; et al. Analysis of miRNA profiles identified miR-196a as a crucial mediator of aberrant PI3K/AKT signaling in lung cancer cells. Oncotarget 2017, 8, 19172-19191. [CrossRef]

166. Faversani, A.; Amatori, S.; Augello, C.; Colombo, F.; Porretti, L.; Fanelli, M.; Ferrero, S.; Palleschi, A.; Pelicci, P.G.; Belloni, E.; et al. miR-494-3p is a novel tumor driver of lung carcinogenesis. Oncotarget. 2017, 8, 7231-7247. [CrossRef]

167. Bai, J.; Zhu, X.; Ma, J.; Wang, W. miR-205 regulates A549 cells proliferation by targeting PTEN. Int. J. Clin. Exp. Pathol. 2015, 8, 1175-1183.

168. Garofalo, M.; Di Leva, G.; Romano, G.; Nuovo, G.; Suh, S.S.; Ngankeu, A.; Taccioli, C.; Pichiorri, F.; Alder, H.; Secchiero, P.; et al. miR-221\&222 regulate TRAIL resistance and enhance tumorigenicity through PTEN and TIMP3 downregulation. Cancer Cell 2009, 16, 498-509. [CrossRef]

169. Zhao, M.; Xu, P.; Liu, Z.; Zhen, Y.; Chen, Y.; Liu, Y.; Fu, Q.; Deng, X.; Liang, Z.; Li, Y.; et al. Dual roles of miR-374a by modulated c-Jun respectively targets CCND1-inducing PI3K/AKT signal and PTEN-suppressing Wnt/ $\beta$-catenin signaling in non-small-cell lung cancer. Cell Death Dis. 2018, 9, 78. [CrossRef]

170. Bach, D.H.; Kim, D.; Bae, S.Y.; Kim, W.K.; Hong, J.Y.; Lee, H.J.; Rajasekaran, N.; Kwon, S.; Fan, Y.; Luu, T.T.; et al. Targeting Nicotinamide N-Methyltransferase and miR-449a in EGFR-TKI-Resistant Non-Small-Cell Lung Cancer Cells. Mol. Ther. Nucleic. Acids 2018, 11, 455-467. [CrossRef]

171. Li, C.; Lyu, J.; Meng, Q.H. MiR-93 Promotes Tumorigenesis and Metastasis of Non-Small Cell Lung Cancer Cells by Activating the PI3K/Akt Pathway via Inhibition of LKB1/PTEN/CDKN1A. J. Cancer 2017, 8, 870-879. [CrossRef]

172. Marin, I.; Ofek, E.; Bar, J.; Prisant, N.; Perelman, M.; Avivi, C.; Lavy-Shahaf, G.; Onn, A.; Katz, R.; Barshack, I. MiR-21, EGFR and PTEN in non-small cell lung cancer: An in situ hybridisation and immunohistochemistry study. J. Clin. Pathol. 2020, 73, 636-641. [CrossRef]

173. Dai, L.; Chen, F.; Zheng, Y.; Zhang, D.; Qian, B.; Ji, H.; Long, F.; Cretoiu, D. miR-21 regulates growth and EMT in lung cancer cells via PTEN/Akt/GSK3 $\beta$ signaling. Front. Biosci. (Landmark Ed) 2019, 24, 1426-1439.

174. Xu, L.F.; Wu, Z.P.; Chen, Y.; Zhu, Q.S.; Hamidi, S.; Navab, R. MicroRNA-21 (miR-21) regulates cellular proliferation, invasion, migration, and apoptosis by targeting PTEN, RECK and Bcl-2 in lung squamous carcinoma, Gejiu City, China. PLoS ONE 2014, 9, e103698. [CrossRef] [PubMed]

175. Liu, B.; Wu, X.; Liu, B.; Wang, C.; Liu, Y.; Zhou, Q.; Xu, K. MiR-26a enhances metastasis potential of lung cancer cells via AKT pathway by targeting PTEN. Biochim. Biophys. Acta 2012, 1822, 1692-1704. [CrossRef] [PubMed]

176. Zhang, J.G.; Wang, J.J.; Zhao, F.; Liu, Q.; Jiang, K.; Yang, G.H. MicroRNA-21 (miR-21) represses tumor suppressor PTEN and promotes growth and invasion in non-small cell lung cancer (NSCLC). Clin. Chim. Acta 2010, 411, 846-852. [CrossRef]

177. Cai, J.; Fang, L.; Huang, Y.; Li, R.; Yuan, J.; Yang, Y.; Zhu, X.; Chen, B.; Wu, J.; Li, M. miR-205 targets PTEN and PHLPP2 to augment AKT signaling and drive malignant phenotypes in non-small cell lung cancer. Cancer Res. 2013, 73, 5402-5415. [CrossRef] [PubMed]

178. Wang, H.; Ma, Z.; Liu, X.; Zhang, C.; Hu, Y.; Ding, L.; Qi, P.; Wang, J.; Lu, S.; Li, Y. MiR-183-5p is required for non-small cell lung cancer progression by repressing PTEN. Biomed. Pharmacother 2019, 111, 1103-1111. [CrossRef] [PubMed]

179. Dastmalchi, N.; Hosseinpourfeizi, M.A.; Khojasteh, S.M.B.; Baradaran, B.; Safaralizadeh, R. Tumor suppressive activity of miR-424-5p in breast cancer cells through targeting PD-L1 and modulating PTEN/PI3K/AKT/mTOR signaling pathway. Life Sci. 2020, 259, 118239. [CrossRef] [PubMed]

180. Yang, W.B.; Zhang, W.P.; Shi, J.L.; Wang, J.W. MiR-4299 suppresses non-small cell lung cancer cell proliferation, migration and invasion through modulating PTEN/AKT/PI3K pathway. Eur. Rev. Med. Pharmacol Sci. 2018, 22, 3408-3414. [CrossRef]

181. Zhang, G.; Wu, Y.J.; Yan, F. MicroRNA-130-5p promotes invasion as well as migration of lung adenocarcinoma cells by targeting the EZH2 signaling pathway. Eur. Rev. Med. Pharmacol Sci 2019, 23, 9480-9488. [CrossRef]

182. Ye, L.; Wang, Y.; Nie, L.; Qian, S.; Xu, M. MiR-130 exerts tumor suppressive function on the tumorigenesis of human non-small cell lung cancer by targeting PTEN. Am. J. Transl. Res. 2017, 9, 1856-1865. [PubMed]

183. De Angelis, M.L.; Francescangeli, F.; Zeuner, A. Breast Cancer Stem Cells as Drivers of Tumor Chemoresistance, Dormancy and Relapse: New Challenges and Therapeutic Opportunities. Cancers 2019, 11, 1569. [CrossRef]

184. Wu, Z.; Niu, T.; Xiao, W. Uev1A promotes breast cancer cell survival and chemoresistance through the AKT-FOXO1-BIM pathway. Cancer Cell Int. 2019, 19, 331. [CrossRef] [PubMed]

185. Yang, Y.L.; Liu, P.; Li, D.; Yang, Q.; Li, B.; Jiang, X.J. Stat-3 signaling promotes cell proliferation and metastasis of gastric cancer through PDCD4 downregulation. Kaohsiung J. Med. Sci. 2020, 36, 244-249. [CrossRef] 
186. Goh, J.N.; Loo, S.Y.; Datta, A.; Siveen, K.S.; Yap, W.N.; Cai, W.; Shin, E.M.; Wang, C.; Kim, J.E.; Chan, M.; et al. microRNAs in breast cancer: Regulatory roles governing the hallmarks of cancer. Biol. Rev. Camb. Philos. Soc. 2016, 91, 409-428. [CrossRef] [PubMed]

187. Loo, S.Y.; Hirpara, J.L.; Pandey, V.; Tan, T.Z.; Yap, C.T.; Lobie, P.E.; Thiery, J.P.; Goh, B.C.; Pervaiz, S.; Clément, M.V.; et al. Manganese Superoxide Dismutase Expression Regulates the Switch Between an Epithelial and a Mesenchymal-Like Phenotype in Breast Carcinoma. Antioxid. Redox Signal. 2016, 25, 283-299. [CrossRef]

188. Yuan, Y.; Anbalagan, D.; Lee, L.H.; Samy, R.P.; Shanmugam, M.K.; Kumar, A.P.; Sethi, G.; Lobie, P.E.; Lim, L.H. ANXA1 inhibits miRNA-196a in a negative feedback loop through NF-kB and c-Myc to reduce breast cancer proliferation. Oncotarget 2016, 7, 27007-27020. [CrossRef]

189. Liang, Z.; Feng, A.; Shim, H. MicroRNA-30c-regulated HDAC9 mediates chemoresistance of breast cancer. Cancer Chemother. Pharmacol. 2020, 85, 413-423. [CrossRef]

190. Zhang, M.; Wang, F.; Xiang, Z.; Huang, T.; Zhou, W.B. LncRNA XIST promotes chemoresistance of breast cancer cells to doxorubicin by sponging miR-200c-3p to upregulate ANLN. Clin. Exp. Pharmacol. Physiol. 2020, 47, 1464-1472. [CrossRef]

191. Wang, D.D.; Yang, S.J.; Chen, X.; Shen, H.Y.; Luo, L.J.; Zhang, X.H.; Zhong, S.L.; Zhao, J.H.; Tang, J.H. miR-222 induces Adriamycin resistance in breast cancer through PTEN/Akt/p27(kip1) pathway. Tumour Biol. 2016, 37, 15315-15324. [CrossRef]

192. Wang, Y.; Chang, J.; Li, Y.-C.; Li, Y.-S.; Shyy, J.Y.-J.; Chien, S. Shear stress and VEGF activate IKK via the Flk-1/Cbl/Akt signaling pathway. Am. J. Physiol. Cell Physiol. 2004, 286, H685-H692. [CrossRef] [PubMed]

193. Manu, K.A.; Shanmugam, M.K.; Ramachandran, L.; Li, F.; Siveen, K.S.; Chinnathambi, A.; Zayed, M.E.; Alharbi, S.A.; Arfuso, F.; Kumar, A.P.; et al. Isorhamnetin augments the anti-tumor effect of capecitabine through the negative regulation of NF- $\mathrm{B}$ signaling cascade in gastric cancer. Cancer Lett. 2015, 363, 28-36. [CrossRef] [PubMed]

194. Ahn, K.S.; Sethi, G.; Jain, A.K.; Jaiswal, A.K.; Aggarwal, B.B. Genetic deletion of NAD(P)H:quinone oxidoreductase 1 abrogates activation of nuclear factor-kappaB, IkappaBalpha kinase, c-Jun N-terminal kinase, Akt, p38, and p44/42 mitogen-activated protein kinases and potentiates apoptosis. J. Biol. Chem. 2006, 281, 19798-19808. [CrossRef] [PubMed]

195. Shanmugam, M.K.; Ong, T.H.; Kumar, A.P.; Lun, C.K.; Ho, P.C.; Wong, P.T.; Hui, K.M.; Sethi, G. Ursolic acid inhibits the initiation, progression of prostate cancer and prolongs the survival of TRAMP mice by modulating pro-inflammatory pathways. PLoS ONE 2012, 7, e32476. [CrossRef]

196. Schmedtje, J.F.; Ji, Y.-S.; Liu, W.-L.; DuBois, R.N.; Runge, M.S. Hypoxia induces cyclooxygenase-2 via the NF-kB p65 transcription factor in human vascular endothelial cells. J. Biol. Chem. 1997, 272, 601-608. [CrossRef]

197. St-Germain, M.-E.; Gagnon, V.; Parent, S.; Asselin, E. Regulation of COX-2 protein expression by Akt in endometrial cancer cells is mediated through NF-кB/IкB pathway. Mol. Cancer 2004, 3, 1-11. [CrossRef]

198. Shin, E.M.; Hay, H.S.; Lee, M.H.; Goh, J.N.; Tan, T.Z.; Sen, Y.P.; Lim, S.W.; Yousef, E.M.; Ong, H.T.; Thike, A.A.; et al. DEAD-box helicase DP103 defines metastatic potential of human breast cancers. J. Clin. Investig. 2014, 124, 3807-3824. [CrossRef]

199. Manu, K.A.; Shanmugam, M.K.; Li, F.; Chen, L.; Siveen, K.S.; Ahn, K.S.; Kumar, A.P.; Sethi, G. Simvastatin sensitizes human gastric cancer xenograft in nude mice to capecitabine by suppressing nuclear factor-kappa B-regulated gene products. J. Mol. Med. 2014, 92, 267-276. [CrossRef]

200. Armoni, M.; Harel, C.; Karni, S.; Chen, H.; Bar-Yoseph, F.; Ver, M.R.; Quon, M.J.; Karnieli, E. FOXO1 represses peroxisome proliferator-activated receptor- $\gamma 1$ and $-\gamma 2$ gene promoters in primary adipocytes A NOVEL PARADIGM TO INCREASE INSULIN SENSITIVITY. J Biol. Chem. 2006, 281, 19881-19891. [CrossRef]

201. Nakae, J.; Oki, M.; Cao, Y. The FoxO transcription factors and metabolic regulation. FEBS Lett. 2008, 582, 54-67. [CrossRef]

202. Greer, E.L.; Brunet, A. FOXO transcription factors at the interface between longevity and tumor suppression. Oncogene 2005, 24, 7410-7425. [CrossRef]

203. Shen, H.; Wang, D.; Li, L.; Yang, S.; Chen, X.; Zhou, S.; Zhong, S.; Zhao, J.; Tang, J. MiR-222 promotes drug-resistance of breast cancer cells to adriamycin via modulation of PTEN/Akt/FOXO1 pathway. Gene 2017, 596, 110-118. [CrossRef]

204. Zhong, S.; Li, W.; Chen, Z.; Xu, J.; Zhao, J. MiR-222 and miR-29a contribute to the drug-resistance of breast cancer cells. Gene 2013, 531, 8-14. [CrossRef] [PubMed]

205. Liang, Z.; Li, Y.; Huang, K.; Wagar, N.; Shim, H. Regulation of miR-19 to breast cancer chemoresistance through targeting PTEN. Pharm. Res. 2011, 28, 3091-3100. [CrossRef]

206. Zhang, J.; Miller, Z.; Musich, P.R.; Thomas, A.E.; Yao, Z.Q.; Xie, Q.; Howe, P.H.; Jiang, Y. DSTYK Promotes Metastasis and Chemoresistance via EMT in Colorectal Cancer. Front. Pharmacol. 2020, 11, 1250. [CrossRef] [PubMed]

207. Ashrafizadeh, M.; Zarrabi, A.; Hushmandi, K.; Kalantari, M.; Mohammadinejad, R.; Javaheri, T.; Sethi, G. Association of the Epithelial-Mesenchymal Transition (EMT) with Cisplatin Resistance. Int. J. Mol. Sci. 2020, 21, 4002. [CrossRef]

208. Cheng, J.T.; Wang, L.; Wang, H.; Tang, F.R.; Cai, W.Q.; Sethi, G.; Xin, H.W.; Ma, Z. Insights into Biological Role of LncRNAs in Epithelial-Mesenchymal Transition. Cells 2019, 8, 1178. [CrossRef]

209. Chu, S.; Liu, G.; Xia, P.; Chen, G.; Shi, F.; Yi, T.; Zhou, H. miR-93 and PTEN: Key regulators of doxorubicin-resistance and EMT in breast cancer. Oncol. Rep. 2017, 38, 2401-2407. [CrossRef] [PubMed]

210. Kuo, T.N.; Lin, C.S.; Li, G.D.; Kuo, C.Y.; Kao, S.H. Sesamin inhibits cervical cancer cell proliferation by promoting p53/PTENmediated apoptosis. Int. J. Med. Sci. 2020, 17, 2292-2298. [CrossRef]

211. Li, S.; Li, Q.; Lü, J.; Zhao, Q.; Li, D.; Shen, L.; Wang, Z.; Liu, J.; Xie, D.; Cho, W.C.; et al. Targeted Inhibition of miR-221/222 Promotes Cell Sensitivity to Cisplatin in Triple-Negative Breast Cancer MDA-MB-231 Cells. Front. Genet. 2019, 10, 1278. [CrossRef] 
212. Geng, W.; Song, H.; Zhao, Q.; Dong, K.; Pu, Q.; Gao, H.; Lv, Y. miR-520h Stimulates Drug Resistance to Paclitaxel by Targeting the OTUD3-PTEN Axis in Breast Cancer. Biomed. Res. Int. 2020, 2020, 9512793. [CrossRef] [PubMed]

213. Liu, J.H.; Chen, C.; Li, Z.Y.; Zou, Z.M.; Gao, D.C.; Zhang, X.; Kuang, X.W.; Sun, Z.H.; Zheng, W.J.; Zhou, P.; et al. The MyD88 inhibitor TJ-M2010-2 suppresses proliferation, migration and invasion of breast cancer cells by regulating MyD88/GSK-3 $\beta$ and MyD88/NF-кB signalling pathways. Exp. Cell Res. 2020, 394, 112157. [CrossRef]

214. Xiong, R.; Sun, X.X.; Wu, H.R.; Xu, G.W.; Wang, G.X.; Sun, X.H.; Xu, M.Q.; Xie, M.R. Mechanism research of miR-34a regulates Axl in non-small-cell lung cancer with gefitinib-acquired resistance. Thorac. Cancer 2020, 11, 156-165. [CrossRef] [PubMed]

215. Chen, X.; Wang, Z.; Tong, F.; Dong, X.; Wu, G.; Zhang, R. lncRNA UCA1 Promotes Gefitinib Resistance as a ceRNA to Target FOSL2 by Sponging miR-143 in Non-small Cell Lung Cancer. Mol. Ther. Nucleic. Acids 2020, 19, 643-653. [CrossRef]

216. Cui, F.; Zhou, Q.; Xiao, K.; Qian, H. MicroRNA-28 promotes the proliferation of non-small-cell lung cancer cells by targeting PTEN. Mol. Med. Rep. 2020, 21, 2589-2596. [CrossRef]

217. Zhou, J.S.; Yang, Z.S.; Cheng, S.Y.; Yu, J.H.; Huang, C.J.; Feng, Q. miRNA-425-5p enhances lung cancer growth via the PTEN/PI3K/AKT signaling axis. BMC Pulm. Med. 2020, 20, 223. [CrossRef] [PubMed]

218. Ku, J.M.; Hong, S.H.; Kim, H.I.; Kim, M.J.; Kim, S.K.; Kim, M.; Choi, S.Y.; Park, J.; Kim, H.K.; Kim, J.H.; et al. Synergistic anticancer effect of combined use of Trichosanthes kirilowii with cisplatin and pemetrexed enhances apoptosis of H1299 non-small-cell lung cancer cells via modulation of ErbB3. Phytomedicine 2020, 66, 153109. [CrossRef]

219. Medina-Reyes, E.I.; Mancera-Rodríguez, M.A.; Delgado-Buenrostro, N.L.; Moreno-Rodríguez, A.; Bautista-Martínez, J.L.; DíazVelásquez, C.E.; Martínez-Alarcón, S.A.; Torrens, H.; de Los Ángeles Godínez-Rodríguez, M.; Terrazas-Valdés, L.I.; et al. Novel thiosemicarbazones induce high toxicity in estrogen-receptor-positive breast cancer cells (MCF7) and exacerbate cisplatin effectiveness in triple-negative breast (MDA-MB231) and lung adenocarcinoma (A549) cells. Invest. New Drugs 2020, 38, 558-573. [CrossRef] [PubMed]

220. Cao, Q.; You, X.; Xu, L.; Wang, L.; Chen, Y. PAQR3 suppresses the growth of non-small cell lung cancer cells via modulation of EGFR-mediated autophagy. Autophagy 2020, 16, 1236-1247. [CrossRef]

221. Liu, J.; Deng, X.; Sun, X.; Dong, J.; Huang, J. Inhibition of autophagy enhances timosaponin AIII-induced lung cancer cell apoptosis and anti-tumor effect in vitro and in vivo. Life Sci. 2020, 257, 118040. [CrossRef]

222. Singh, S.S.; Vats, S.; Chia, A.Y.; Tan, T.Z.; Deng, S.; Ong, M.S.; Arfuso, F.; Yap, C.T.; Goh, B.C.; Sethi, G.; et al. Dual role of autophagy in hallmarks of cancer. Oncogene 2018, 37, 1142-1158. [CrossRef]

223. Deng, S.; Shanmugam, M.K.; Kumar, A.P.; Yap, C.T.; Sethi, G.; Bishayee, A. Targeting autophagy using natural compounds for cancer prevention and therapy. Cancer 2019, 125, 1228-1246. [CrossRef]

224. Bordoloi, D.; Banik, K.; Shabnam, B.; Padmavathi, G.; Monisha, J.; Arfuso, F.; Dharmarajan, A.; Mao, X.; Lim, L.H.K.; Wang, L.; et al. TIPE Family of Proteins and Its Implications in Different Chronic Diseases. Int. J. Mol. Sci. 2018, 19, 2974. [CrossRef] [PubMed]

225. Liu, J.; Xing, Y.; Rong, L. miR-181 regulates cisplatin-resistant non-small cell lung cancer via downregulation of autophagy through the PTEN/PI3K/AKT pathway. Oncol. Rep. 2018, 39, 1631-1639. [CrossRef]

226. Chen, L.-M.; Song, T.-J.; Xiao, J.-H.; Huang, Z.-H.; Li, Y.; Lin, T.-Y. Tripchlorolide induces autophagy in lung cancer cells by inhibiting the PI3K/AKT/mTOR pathway and improves cisplatin sensitivity in A549/DDP cells. Oncotarget 2017, 8, 63911. [CrossRef] [PubMed]

227. Wang, X.; Shao, Q.H.; Zhou, H.; Wu, J.L.; Quan, W.Q.; Ji, P.; Yao, Y.W.; Li, D.; Sun, Z.J. Ginkgolide B inhibits lung cancer cells promotion via beclin-1-dependent autophagy. BMC Complement Med. Ther. 2020, 20, 194. [CrossRef]

228. Jia, R.; Wang, C. MiR-29b-3p Reverses Cisplatin Resistance by Targeting COL1A1 in Non-Small-Cell Lung Cancer A549/DDP Cells. Cancer Manag. Res. 2020, 12, 2559-2566. [CrossRef]

229. Han, Z.; Zhou, X.; Li, S.; Qin, Y.; Chen, Y.; Liu, H. Inhibition of miR-23a increases the sensitivity of lung cancer stem cells to erlotinib through PTEN/PI3K/Akt pathway. Oncol. Rep. 2017, 38, 3064-3070. [CrossRef]

230. Shen, K.H.; Hung, J.H.; Liao, Y.C.; Tsai, S.T.; Wu, M.J.; Chen, P.S. Sinomenine Inhibits Migration and Invasion of Human Lung Cancer Cell through Downregulating Expression of miR-21 and MMPs. Int. J. Mol. Sci. 2020, 21, 3080. [CrossRef]

231. Cheng, Y.; Yu, C.; Li, W.; He, Y.; Bao, Y. Matrine Inhibits Proliferation, Invasion, and Migration and Induces Apoptosis of Colorectal Cancer Cells Via miR-10b/PTEN Pathway. Cancer Biother. Radiopharm. 2020. [CrossRef] [PubMed]

232. Shen, H.; Zhu, F.; Liu, J.; Xu, T.; Pei, D.; Wang, R.; Qian, Y.; Li, Q.; Wang, L.; Shi, Z.; et al. Alteration in Mir-21/PTEN expression modulates gefitinib resistance in non-small cell lung cancer. PLoS ONE 2014, 9, e103305. [CrossRef] [PubMed]

233. Dong, C.; Liu, X.; Wang, H.; Li, J.; Dai, L.; Li, J.; Xu, Z. Hypoxic non-small-cell lung cancer cell-derived exosomal miR-21 promotes resistance of normoxic cell to cisplatin. Onco. Targets Ther. 2019, 12, 1947-1956. [CrossRef] [PubMed]

234. Li, B.; Ren, S.; Li, X.; Wang, Y.; Garfield, D.; Zhou, S.; Chen, X.; Su, C.; Chen, M.; Kuang, P.; et al. MiR-21 overexpression is associated with acquired resistance of EGFR-TKI in non-small cell lung cancer. Lung Cancer 2014, 83, 146-153. [CrossRef] [PubMed]

235. Liu, Z.L.; Wang, H.; Liu, J.; Wang, Z.X. MicroRNA-21 (miR-21) expression promotes growth, metastasis, and chemo- or radioresistance in non-small cell lung cancer cells by targeting PTEN. Mol. Cell Biochem. 2013, 372, 35-45. [CrossRef]

236. Chen, L.; Liu, D.; Yi, X.; Qi, L.; Tian, X.; Sun, B.; Dong, Q.; Han, Z.; Li, Q.; Song, T.; et al. The novel miR-1269b-regulated protein SVEP1 induces hepatocellular carcinoma proliferation and metastasis likely through the PI3K/Akt pathway. Cell Death Dis. 2020, 11, 320. [CrossRef] 
237. Yang, W.; Xiao, W.; Cai, Z.; Jin, S.; Li, T. miR-1269b Drives Cisplatin Resistance of Human Non-Small Cell Lung Cancer via Modulating the PTEN/PI3K/AKT Signaling Pathway. Onco. Targets Ther. 2020, 13, 109-118. [CrossRef]

238. Lei, L.; Huang, Y.; Gong, W. miR-205 promotes the growth, metastasis and chemoresistance of NSCLC cells by targeting PTEN. Oncol. Rep. 2013, 30, 2897-2902. [CrossRef]

239. Sailo, B.L.; Banik, K.; Girisa, S.; Bordoloi, D.; Fan, L.; Halim, C.E.; Wang, H.; Kumar, A.P.; Zheng, D.; Mao, X.; et al. FBXW7 in Cancer: What Has Been Unraveled Thus Far? Cancers 2019, 11, 246. [CrossRef]

240. Monisha, J.; Roy, N.K.; Padmavathi, G.; Banik, K.; Bordoloi, D.; Khwairakpam, A.D.; Arfuso, F.; Chinnathambi, A.; Alahmadi, T.A.; Alharbi, S.A.; et al. NGAL is Downregulated in Oral Squamous Cell Carcinoma and Leads to Increased Survival, Proliferation, Migration and Chemoresistance. Cancers 2018, 10, 228. [CrossRef]

241. Raghunath, A.; Sundarraj, K.; Arfuso, F.; Sethi, G.; Perumal, E. Dysregulation of Nrf2 in Hepatocellular Carcinoma: Role in Cancer Progression and Chemoresistance. Cancers 2018, 10, 481. [CrossRef] [PubMed]

242. Zhu, M.; Jiang, B.; Yan, D.; Wang, X.; Ge, H.; Sun, Y. Knockdown of TMEM45A overcomes multidrug resistance and epithelialmesenchymal transition in human colorectal cancer cells through inhibition of TGF- $\beta$ signalling pathway. Clin. Exp. Pharmacol. Physiol. 2020, 47, 503-516. [CrossRef] [PubMed]

243. Qiao, Y.; Wang, Z.; Tan, F.; Chen, J.; Lin, J.; Yang, J.; Li, H.; Wang, X.; Sali, A.; Zhang, L.; et al. Enhancer Reprogramming within Pre-existing Topologically Associated Domains Promotes TGF- $\beta$-Induced EMT and Cancer Metastasis. Mol. Ther. 2020, 28, 2083-2095. [CrossRef]

244. Ko, J.H.; Nam, D.; Um, J.Y.; Jung, S.H.; Sethi, G.; Ahn, K.S. Bergamottin Suppresses Metastasis of Lung Cancer Cells through Abrogation of Diverse Oncogenic Signaling Cascades and Epithelial-to-Mesenchymal Transition. Molecules 2018, $23,1601$. [CrossRef]

245. Hwang, S.T.; Yang, M.H.; Kumar, A.P.; Sethi, G.; Ahn, K.S. Corilagin Represses Epithelial to Mesenchymal Transition Process Through Modulating Wnt/ $\beta$-Catenin Signaling Cascade. Biomolecules 2020, 10, 1406. [CrossRef]

246. Kitamura, K.; Seike, M.; Okano, T.; Matsuda, K.; Miyanaga, A.; Mizutani, H.; Noro, R.; Minegishi, Y.; Kubota, K.; Gemma, A. MiR-134/487b/ 655 cluster regulates TGF- $\beta$-induced epithelial-mesenchymal transition and drug resistance to gefitinib by targeting MAGI2 in lung adenocarcinoma cells. Mol. Cancer Ther. 2014, 13, 444-453. [CrossRef] [PubMed]

247. Yang, Z.; Fang, S.; Di, Y.; Ying, W.; Tan, Y.; Gu, W. Modulation of NF-kB/miR-21/PTEN pathway sensitizes non-small cell lung cancer to cisplatin. PLoS ONE 2015, 10, e0121547. [CrossRef] [PubMed]

248. Li, Y.; Li, L.; Guan, Y.; Liu, X.; Meng, Q.; Guo, Q. MiR-92b regulates the cell growth, cisplatin chemosensitivity of A549 non small cell lung cancer cell line and target PTEN. Biochem. Biophys. Res. Commun. 2013, 440, 604-610. [CrossRef] [PubMed]

249. Xiao, H.; Liu, Y.; Liang, P.; Wang, B.; Tan, H.; Zhang, Y.; Gao, X.; Gao, J. TP53TG1 enhances cisplatin sensitivity of non-small cell lung cancer cells through regulating miR-18a/PTEN axis. Cell Biosci. 2018, 8, 23. [CrossRef] [PubMed]

250. Luan, Y.; Li, X.; Luan, Y.; Zhao, R.; Li, Y.; Liu, L.; Hao, Y.; Oleg Vladimir, B.; Jia, L. Circulating lncRNA UCA1 Promotes Malignancy of Colorectal Cancer via the miR-143/MYO6 Axis. Mol. Ther. Nucleic. Acids. 2020, 19, 790-803. [CrossRef]

251. Liu, G.; Liu, S.; Xing, G.; Wang, F. lncRNA PVT1/MicroRNA-17-5p/PTEN Axis Regulates Secretion of E2 and P4, Proliferation, and Apoptosis of Ovarian Granulosa Cells in PCOS. Mol. Ther. Nucleic. Acids. 2020, 20, 205-216. [CrossRef]

252. Zhu, X.P.; Pan, S.A.; Chu, Z.; Zhou, Y.X.; Huang, Y.K.; Han, D.Q. LncRNA GAS5 regulates epithelial-mesenchymal transition and viability of glioma cells by targeting microRNA-106b and regulating PTEN expression. Neurosci Res. 2020. [CrossRef]

253. Gao, X.; Qin, T.; Mao, J.; Zhang, J.; Fan, S.; Lu, Y.; Sun, Z.; Zhang, Q.; Song, B.; Li, L. PTENP1/miR-20a/PTEN axis contributes to breast cancer progression by regulating PTEN via PI3K/AKT pathway. J. Exp. Clin. Cancer Res 2019, 38, 256. [CrossRef]

254. Shi, X.; Tang, X.; Su, L. Overexpression of Long Noncoding RNA PTENP1 Inhibits Cell Proliferation and Migration via Suppression of miR-19b in Breast Cancer Cells. Oncol. Res. 2018, 26, 869-878. [CrossRef] [PubMed]

255. Gu, J.; Wang, Y.; Wang, X.; Zhou, D.; Shao, C.; Zhou, M.; He, Z. Downregulation of lncRNA GAS5 confers tamoxifen resistance by activating miR-222 in breast cancer. Cancer lett. 2018, 434, 1-10. [CrossRef]

256. Shao, G.; Zhao, Z.; Zhao, W.; Hu, G.; Zhang, L.; Li, W.; Xing, C.; Zhang, X. Long non-coding RNA MALAT1 activates autophagy and promotes cell proliferation by downregulating microRNA-204 expression in gastric cancer. Oncol. Lett. 2020, 19, 805-812 [CrossRef]

257. Lu, Q.; Liu, T.; Feng, H.; Yang, R.; Zhao, X.; Chen, W.; Jiang, B.; Qin, H.; Guo, X.; Liu, M.; et al. Circular RNA circSLC8A1 acts as a sponge of miR-130b/miR-494 in suppressing bladder cancer progression via regulating PTEN. Mol. Cancer 2019, 18, 111. [CrossRef]

258. Zhu, Q.; Zhang, X.; Zai, H.Y.; Jiang, W.; Zhang, K.J.; He, Y.Q.; Hu, Y. circSLC8A1 sponges miR-671 to regulate breast cancer tumorigenesis via PTEN/PI3k/Akt pathway. Genomics 2020. [CrossRef]

259. Zhang, X.Y.; Mao, L. Circular RNA Circ_0000442 acts as a sponge of MiR-148b-3p to suppress breast cancer via PTEN/PI3K/Akt signaling pathway. Gene 2021, 766, 145113. [CrossRef] [PubMed]

260. Griffith, T.S.; Lynch, D.H. TRAIL: A molecule with multiple receptors and control mechanisms. Curr. Opin. Immunol. 1998, 10, 559-563. [CrossRef]

261. Rahman, M.; Davis, S.R.; Pumphrey, J.G.; Bao, J.; Nau, M.M.; Meltzer, P.S.; Lipkowitz, S. TRAIL induces apoptosis in triplenegative breast cancer cells with a mesenchymal phenotype. Breast Cancer Res. Treat. 2009, 113, 217-230. [CrossRef]

262. Wang, H.; Xu, C.; Kong, X.; Li, X.; Kong, X.; Wang, Y.; Ding, X.; Yang, Q. Trail resistance induces epithelial-mesenchymal transition and enhances invasiveness by suppressing PTEN via miR-221 in breast cancer. PLoS ONE 2014, 9, e99067. [CrossRef] 
263. Su, S.; Chen, J.; Yao, H.; Liu, J.; Yu, S.; Lao, L.; Wang, M.; Luo, M.; Xing, Y.; Chen, F.; et al. CD10(+)GPR77(+) Cancer-Associated Fibroblasts Promote Cancer Formation and Chemoresistance by Sustaining Cancer Stemness. Cell 2018, 172, 841-856. [CrossRef]

264. Ershaid, N.; Sharon, Y.; Doron, H.; Raz, Y.; Shani, O.; Cohen, N.; Monteran, L.; Leider-Trejo, L.; Ben-Shmuel, A.; Yassin, M.; et al. NLRP3 inflammasome in fibroblasts links tissue damage with inflammation in breast cancer progression and metastasis. Nat. Commun. 2019, 10, 4375. [CrossRef]

265. Vennin, C.; Mélénec, P.; Rouet, R.; Nobis, M.; Cazet, A.S.; Murphy, K.J.; Herrmann, D.; Reed, D.A.; Lucas, M.C.; Warren, S.C.; et al. CAF hierarchy driven by pancreatic cancer cell p53-status creates a pro-metastatic and chemoresistant environment via perlecan. Nat. Commun. 2019, 10, 3637. [CrossRef]

266. Gao, Y.; Li, X.; Zeng, C.; Liu, C.; Hao, Q.; Li, W.; Zhang, K.; Zhang, W.; Wang, S.; Zhao, H.; et al. CD63(+) Cancer-Associated Fibroblasts Confer Tamoxifen Resistance to Breast Cancer Cells through Exosomal miR-22. Adv. Sci. (Weinh) 2020, 7, 2002518. [CrossRef] [PubMed]

267. Muppala, S.; Mudduluru, G.; Leupold, J.H.; Buergy, D.; Sleeman, J.P.; Allgayer, H. CD24 induces expression of the oncomir miR-21 via Src, and CD24 and Src are both post-transcriptionally downregulated by the tumor suppressor miR-34a. PLoS ONE 2013, 8, e59563. [CrossRef]

268. Shi, Z.; Zhang, J.; Qian, X.; Han, L.; Zhang, K.; Chen, L.; Liu, J.; Ren, Y.; Yang, M.; Zhang, A.; et al. AC1MMYR2, an inhibitor of dicer-mediated biogenesis of Oncomir miR-21, reverses epithelial-mesenchymal transition and suppresses tumor growth and progression. Cancer Res. 2013, 73, 5519-5531. [CrossRef] [PubMed]

269. Dong, L.; Li, G.; Li, Y.; Zhu, Z. Upregulation of Long Noncoding RNA GAS5 Inhibits Lung Cancer Cell Proliferation and Metastasis via miR-205/PTEN Axis. Med. Sci. Monit. 2019, 25, 2311-2319. [CrossRef]

270. Cao, L.; Chen, J.; Ou, B.; Liu, C.; Zou, Y.; Chen, Q. GAS5 knockdown reduces the chemo-sensitivity of non-small cell lung cancer (NSCLC) cell to cisplatin (DDP) through regulating miR-21/PTEN axis. Biomed. Pharmacother. 2017, 93, 570-579. [CrossRef] [PubMed]

271. Chen, L.; Ren, P.; Zhang, Y.; Gong, B.; Yu, D.; Sun, X. Long non-coding RNA GAS5 increases the radiosensitivity of A549 cells through interaction with the miR-21/PTEN/Akt axis. Oncol. Rep. 2020, 43, 897-907. [CrossRef]

272. Xiang, C.; Zhang, Y.; Zhang, Y.; Liu, C.; Hou, Y.; Zhang, Y. lncRNA LEF1-AS1 Promotes Proliferation and Induces Apoptosis of Non-Small-Cell Lung Cancer Cells by Regulating miR-221/PTEN Signaling. Cancer Manag. Res. 2020, 12, 3845-3850. [CrossRef]

273. Samec, M.; Liskova, A.; Koklesova, L.; Samuel, S.M.; Zhai, K.; Buhrmann, C.; Varghese, E.; Abotaleb, M.; Qaradakhi, T.; Zulli, A.; et al. Flavonoids against the Warburg phenotype-Concepts of predictive, preventive and personalised medicine to cut the Gordian knot of cancer cell metabolism. EPMA J. 2020, 11, 377-398. [CrossRef] [PubMed]

274. Lu, H.; Guo, Q.; Mao, G.; Zhu, J.; Li, F. CircLARP4 Suppresses Cell Proliferation, Invasion and Glycolysis and Promotes Apoptosis in Non-Small Cell Lung Cancer by Targeting miR-135b. Onco. Targets Ther. 2020, 13, 3717-3728. [CrossRef] [PubMed]

275. Li, F.; Shanmugam, M.K.; Chen, L.; Chatterjee, S.; Basha, J.; Kumar, A.P.; Kundu, T.K.; Sethi, G. Garcinol, a polyisoprenylated benzophenone modulates multiple proinflammatory signaling cascades leading to the suppression of growth and survival of head and neck carcinoma. Cancer Prev. Res. (Philadelphia, Pa.) 2013, 6, 843-854. [CrossRef]

276. Puar, Y.R.; Shanmugam, M.K.; Fan, L.; Arfuso, F.; Sethi, G.; Tergaonkar, V. Evidence for the Involvement of the Master Transcription Factor NF-kB in Cancer Initiation and Progression. Biomedicines 2018, 6, 82. [CrossRef] [PubMed]

277. Jung, Y.Y.; Shanmugam, M.K.; Chinnathambi, A.; Alharbi, S.A.; Shair, O.H.M.; Um, J.Y.; Sethi, G.; Ahn, K.S. Fangchinoline, a Bisbenzylisoquinoline Alkaloid can Modulate Cytokine-Impelled Apoptosis via the Dual Regulation of NF- $\mathrm{kB}$ and AP-1 Pathways. Molecules 2019, 24, 3127. [CrossRef] [PubMed]

278. Attafi, I.M.; Bakheet, S.A.; Korashy, H.M. The role of NF- $\mathrm{B}$ and AhR transcription factors in lead-induced lung toxicity in human lung cancer A549 cells. Toxicol. Mech. Methods 2020, 30, 197-207. [CrossRef]

279. He, H.; Xu, C.; Zheng, L.; Wang, K.; Jin, M.; Sun, Y.; Yue, Z. Polyphyllin VII induces apoptotic cell death via inhibition of the PI3K/Akt and NF-kB pathways in A549 human lung cancer cells. Mol. Med. Rep. 2020, 21, 597-606. [CrossRef] [PubMed]

280. Li, F.; Shanmugam, M.K.; Siveen, K.S.; Wang, F.; Ong, T.H.; Loo, S.Y.; Swamy, M.M.; Mandal, S.; Kumar, A.P.; Goh, B.C.; et al. Garcinol sensitizes human head and neck carcinoma to cisplatin in a xenograft mouse model despite downregulation of proliferative biomarkers. Oncotarget 2015, 6, 5147-5163. [CrossRef] [PubMed]

281. Kim, C.; Cho, S.K.; Kim, K.D.; Nam, D.; Chung, W.S.; Jang, H.J.; Lee, S.G.; Shim, B.S.; Sethi, G.; Ahn, K.S. $\beta$-Caryophyllene oxide potentiates $\mathrm{TNF} \alpha$-induced apoptosis and inhibits invasion through down-modulation of NF- $\mathrm{kB}$-regulated gene products. Apoptosis 2014, 19, 708-718. [CrossRef] [PubMed]

282. Morgan, D.; Garg, M.; Tergaonkar, V.; Tan, S.Y.; Sethi, G. Pharmacological significance of the non-canonical NF- $\mathrm{B}$ pathway in tumorigenesis. BBA 2020, 188449. [CrossRef]

283. Akgun, S.; Kucuksayan, H.; Ozes, O.N.; Can, O.; Alikanoglu, A.S.; Yildiz, M.; Akca, H. NF-kB-Induced Upregulation of miR-548as-3p Increases Invasion of NSCLC by Targeting PTEN. Anticancer Agents Med. Chem. 2019, 19, 1058-1068. [CrossRef]

284. Tong, L.; Luo, Y.; Wei, T.; Guo, L.; Wang, H.; Zhu, W.; Zhang, J. KH-type splicing regulatory protein (KHSRP) contributes to tumorigenesis by promoting miR-26a maturation in small cell lung cancer. Mol. Cell Biochem. 2016, 422, 61-74. [CrossRef] [PubMed]

285. Borah, A.; Pillai, S.C.; Rochani, A.K.; Palaninathan, V.; Nakajima, Y.; Maekawa, T.; Kumar, D.S. GANT61 and curcumin-loaded PLGA nanoparticles for GLI1 and PI3K/Akt-mediated inhibition in breast adenocarcinoma. Nanotechnology 2020, $31,185102$. [CrossRef] 
286. Guney Eskiler, G.; Sahin, E.; Deveci Ozkan, A.; Cilingir Kaya, O.T.; Kaleli, S. Curcumin induces DNA damage by mediating homologous recombination mechanism in triple negative breast cancer. Nutr. Cancer 2020, 72, 1057-1066. [CrossRef] [PubMed]

287. Ashrafizadeh, M.; Zarrabi, A.; Hashemi, F.; Zabolian, A.; Saleki, H.; Bagherian, M.; Azami, N.; Bejandi, A.K.; Hushmandi, K.; Ang, H.L.; et al. Polychemotherapy with Curcumin and Doxorubicin via Biological Nanoplatforms: Enhancing Antitumor Activity. Pharmaceutics 2020, 12, 1084. [CrossRef]

288. Mishra, S.; Verma, S.S.; Rai, V.; Awasthee, N.; Chava, S.; Hui, K.M.; Kumar, A.P.; Challagundla, K.B.; Sethi, G.; Gupta, S.C. Long non-coding RNAs are emerging targets of phytochemicals for cancer and other chronic diseases. CMLS 2019, 76, 1947-1966. [CrossRef] [PubMed]

289. Shanmugam, M.K.; Warrier, S.; Kumar, A.P.; Sethi, G.; Arfuso, F. Potential Role of Natural Compounds as Anti-Angiogenic Agents in Cancer. Curr. Vasc. Pharmacol. 2017, 15, 503-519. [CrossRef] [PubMed]

290. Moballegh Nasery, M.; Abadi, B.; Poormoghadam, D.; Zarrabi, A.; Keyhanvar, P.; Khanbabaei, H.; Ashrafizadeh, M.; Mohammadinejad, R.; Tavakol, S.; Sethi, G. Curcumin Delivery Mediated by Bio-Based Nanoparticles: A Review. Molecules 2020, $25,689$. [CrossRef]

291. Borges, G.A.; Elias, S.T.; Amorim, B.; de Lima, C.L.; Coletta, R.D.; Castilho, R.M.; Squarize, C.H.; Guerra, E.N.S. Curcumin downregulates the PI3K-AKT-mTOR pathway and inhibits growth and progression in head and neck cancer cells. Phytother. Res. 2020, 34, 3311-3324. [CrossRef]

292. Liu, B.; Shen, Y.; Huang, H.; Croce, K.D.; Wu, M.; Fan, Y.; Liu, Y.; Xu, J.; Yao, G. Curcumin derivative C212 inhibits Hsp90 and eliminates both growing and quiescent leukemia cells in deep dormancy. Cell Commun. Signal 2020, 18, 159. [CrossRef]

293. Mohammed, F.; Rashid-Doubell, F.; Taha, S.; Cassidy, S.; Fredericks, S. Effects of curcumin complexes on MDA-MB-231 breast cancer cell proliferation. Int. J. Oncol. 2020, 57, 445-455. [CrossRef]

294. Wang, N.; Feng, T.; Liu, X.; Liu, Q. Curcumin inhibits migration and invasion of non-small cell lung cancer cells through up-regulation of miR-206 and suppression of PI3K/AKT/mTOR signaling pathway. Acta. Pharm. 2020, 70, 399-409. [CrossRef]

295. Zhou, C.; Hu, C.; Wang, B.; Fan, S.; Jin, W. Curcumin Suppresses Cell Proliferation, Migration, and Invasion Through Modulating miR-21-5p/SOX6 Axis in Hepatocellular Carcinoma. Cancer Biother. Radiopharm. 2020. [CrossRef] [PubMed]

296. Ashrafizadeh, M.; Zarrabi, A.; Hashemipour, M.; Vosough, M.; Najafi, M.; Shahinozzaman, M.; Hushmandi, K.; Khan, H.; Mirzaei, H. Sensing the scent of death: Modulation of microRNAs by Curcumin in gastrointestinal cancers. Pharmacol. Res. 2020, 160, 105199. [CrossRef] [PubMed]

297. Kumar, G.; Mittal, S.; Sak, K.; Tuli, H.S. Molecular mechanisms underlying chemopreventive potential of curcumin: Current challenges and future perspectives. Life Sci. 2016, 148, 313-328. [CrossRef]

298. Wang, Z.; Liu, F.; Liao, W.; Yu, L.; Hu, Z.; Li, M.; Xia, H. Curcumin suppresses glioblastoma cell proliferation by p-AKT/mTOR pathway and increases the PTEN expression. Arch. Biochem. Biophys. 2020, 689, 108412. [CrossRef] [PubMed]

299. Gao, L.; Shao, T.; Zheng, W.; Ding, J. Curcumin suppresses tumor growth of gemcitabine-resistant non-small cell lung cancer by regulating lncRNA-MEG3 and PTEN signaling. Clin. Transl. Oncol. 2021. [CrossRef]

300. Li, X.; Xie, W.; Xie, C.; Huang, C.; Zhu, J.; Liang, Z.; Deng, F.; Zhu, M.; Zhu, W.; Wu, R.; et al. Curcumin modulates miR19/PTEN/AKT/p53 axis to suppress bisphenol A-induced MCF-7 breast cancer cell proliferation. Phytother. Res. 2014, 28, 1553-1560. [CrossRef]

301. Wang, X.; Hang, Y.; Liu, J.; Hou, Y.; Wang, N.; Wang, M. Anticancer effect of curcumin inhibits cell growth through miR21/PTEN/Akt pathway in breast cancer cell. Oncol. Lett. 2017, 13, 4825-4831. [CrossRef]

302. Ibrahim, H.I.; Ismail, M.B.; Ammar, R.B.; Ahmed, E. Thidiazuron suppresses breast cancer progression via targeting miR-132 and miR-202-5p/PTEN axis mediated dysregulation of PI3K/AKT signaling pathway. Biochem. Cell Biol. 2020. [CrossRef] [PubMed]

303. Efferth, T.; Rauh, R.; Kahl, S.; Tomicic, M.; Böchzelt, H.; Tome, M.E.; Briehl, M.M.; Bauer, R.; Kaina, B. Molecular modes of action of cantharidin in tumor cells. Biochem. Pharmacol. 2005, 69, 811-818. [CrossRef]

304. Zheng, L.H.; Bao, Y.L.; Wu, Y.; Yu, C.L.; Meng, X.; Li, Y.X. Cantharidin reverses multidrug resistance of human hepatoma HepG2/ADM cells via down-regulation of P-glycoprotein expression. Cancer Lett. 2008, 272, 102-109. [CrossRef]

305. Sagawa, M.; Nakazato, T.; Uchida, H.; Ikeda, Y.; Kizaki, M. Cantharidin induces apoptosis of human multiple myeloma cells via inhibition of the JAK/STAT pathway. Cancer Sci. 2008, 99, 1820-1826. [CrossRef]

306. Zhang, H.; Yan, X. Cantharidin modulates the E2F1/MCM7-miR-106b-93/p21-PTEN signaling axis in MCF-7 breast cancer cells. Oncol. Lett. 2015, 10, 2849-2855. [CrossRef] [PubMed]

307. Chen, Q.; Shen, H.; Zhu, X.; Liu, Y.; Yang, H.; Chen, H.; Xiong, S.; Chi, H.; Xu, W. A nuclear lncRNA Linc00839 as a Myc target to promote breast cancer chemoresistance via PI3K/AKT signaling pathway. Cancer Sci. 2020, 111, 3279-3291. [CrossRef]

308. Li, L.Q.; Li, X.L.; Wang, L.; Du, W.J.; Guo, R.; Liang, H.H.; Liu, X.; Liang, D.S.; Lu, Y.J.; Shan, H.L.; et al. Matrine inhibits breast cancer growth via miR-21/PTEN/Akt pathway in MCF-7 cells. Cell Physiol. Biochem. 2012, 30, 631-641. [CrossRef]

309. Cabello, P.; Pineda, B.; Tormo, E.; Lluch, A.; Eroles, P. The Antitumor Effect of Metformin Is Mediated by miR-26a in Breast Cancer. Int. J. Mol. Sci. 2016, 17, 1298. [CrossRef]

310. Wu, S.Y.; Wu, A.T.; Yuan, K.S.; Liu, S.H. Brown Seaweed Fucoidan Inhibits Cancer Progression by Dual Regulation of mir29c/ADAM12 and miR-17-5p/PTEN Axes in Human Breast Cancer Cells. J. Cancer 2016, 7, 2408-2419. [CrossRef] [PubMed]

311. Peng, F.; Tang, H.; Liu, P.; Shen, J.; Guan, X.; Xie, X.; Gao, J.; Xiong, L.; Jia, L.; Chen, J.; et al. Isoliquiritigenin modulates miR-374a/PTEN/Akt axis to suppress breast cancer tumorigenesis and metastasis. Sci. Rep. 2017, 7, 9022. [CrossRef] 
312. de la Parra, C.; Castillo-Pichardo, L.; Cruz-Collazo, A.; Cubano, L.; Redis, R.; Calin, G.A.; Dharmawardhane, S. Soy Isoflavone Genistein-Mediated Downregulation of miR-155 Contributes to the Anticancer Effects of Genistein. Nutr. Cancer 2016, 68, 154-164. [CrossRef]

313. Jahanafrooz, Z.; Motamed, N.; Bakhshandeh, B. Effects of miR-21 downregulation and silibinin treatment in breast cancer cell lines. Cytotechnology 2017, 69, 667-680. [CrossRef] [PubMed]

314. Li, F.; Cui, H.; Jin, X.; Gong, X.; Wang, W.; Wang, J. Triptolide inhibits epithelial-mesenchymal transition and induces apoptosis in gefitinib-resistant lung cancer cells. Oncol Rep. 2020, 43, 1569-1579. [CrossRef]

315. Philips, B.J.; Kumar, A.; Burki, S.; Ryan, J.P.; Noda, K.; D’Cunha, J. Triptolide-induced apoptosis in non-small cell lung cancer via a novel miR204-5p/Caveolin-1/Akt-mediated pathway. Oncotarget 2020, 11, 2793-2806. [CrossRef] [PubMed]

316. Li, X.; Zang, A.; Jia, Y.; Zhang, J.; Fan, W.; Feng, J.; Duan, M.; Zhang, L.; Huo, R.; Jiao, J.; et al. Triptolide reduces proliferation and enhances apoptosis of human non-small cell lung cancer cells through PTEN by targeting miR-21. Mol. Med. Rep. 2016, 13, 2763-2768. [CrossRef] [PubMed]

317. Lu, C.; Wang, H.; Chen, S.; Yang, R.; Li, H.; Zhang, G. Baicalein inhibits cell growth and increases cisplatin sensitivity of A549 and H460 cells via miR-424-3p and targeting PTEN/PI3K/Akt pathway. J. Cell Mol. Med. 2018, 22, 2478-2487. [CrossRef]

318. Spear, J.M.; Lu, Z.; Russu, W.A. Pharmacological Inhibition of CDK8 in Triple-Negative Breast Cancer Cell Line MDA-MB-468 Increases E2F1 Protein, Induces Phosphorylation of STAT3 and Apoptosis. Molecules 2020, 25, 5728. [CrossRef] [PubMed]

319. Ma, J.; Fang, L.; Yang, Q.; Hibberd, S.; Du, W.W.; Wu, N.; Yang, B.B. Posttranscriptional regulation of AKT by circular RNA angiomotin- like 1 mediates chemoresistance against paclitaxel in breast cancer cells. Aging 2019, 11, 11369-11381. [CrossRef] [PubMed]

320. Xiao, Z.; Chen, S.; Feng, S.; Li, Y.; Zou, J.; Ling, H.; Zeng, Y.; Zeng, X. Function and mechanisms of microRNA-20a in colorectal cancer. Exp. Ther. Med. 2020, 19, 1605-1616. [CrossRef]

321. Liu, F.; Qiu, F.; Fu, M.; Chen, H.; Wang, H. Propofol Reduces Epithelial to Mesenchymal Transition, Invasion and Migration of Gastric Cancer Cells through the MicroRNA-195-5p/Snail Axis. Med. Sci. Monit. 2020, 26, 920981. [CrossRef]

322. Xu, Y.; Pan, S.; Jiang, W.; Xue, F.; Zhu, X. Effects of propofol on the development of cancer in humans. Cell Proliferation 2020, 53, 12867. [CrossRef] [PubMed]

323. Zheng, X.; Dong, L.; Zhao, S.; Li, Q.; Liu, D.; Zhu, X.; Ge, X.; Li, R.; Wang, G. Propofol Affects Non-Small-Cell Lung Cancer Cell Biology By Regulating the miR-21/PTEN/AKT Pathway In Vitro and In Vivo. Anesth. Analg. 2020, 131, 1270-1280. [CrossRef] [PubMed]

324. Yang, Q.; Wang, P.; Cui, J.; Wang, W.; Chen, Y.; Zhang, T. Panax notoginseng saponins attenuate lung cancer growth in part through modulating the level of Met/miR-222 axis. J. Ethnopharmacol. 2016, 193, 255-265. [CrossRef] [PubMed] 